\title{
Sperm Sensory Signaling
}

\author{
Dagmar Wachten, ${ }^{1}$ Jan F. Jikeli, ${ }^{1}$ and U. Benjamin Kaupp ${ }^{2}$ \\ ${ }^{1}$ Minerva Max Planck Research Group, Molecular Physiology, Center of Advanced European Studies \\ and Research (caesar), 53175 Bonn, Germany \\ ${ }^{2}$ Department Molecular Sensory Systems, Center of Advanced European Studies and Research (caesar), \\ 53175 Bonn, Germany \\ Correspondence: dagmar.wachten@caesar.de; u.b.kaupp@caesar.de
}

Fertilization is exceptionally complex and, depending on the species, happens in entirely different environments. External fertilizers in aquatic habitats, like marine invertebrates or fish, release their gametes into the seawater or freshwater, whereas sperm from most internal fertilizers like mammals cross the female genital tract to make their way to the egg. Various chemical and physical cues guide sperm to the egg. Quite generally, these cues enable signaling pathways that ultimately evoke a cellular $\mathrm{Ca}^{2+}$ response that modulates the waveform of the flagellar beat and, hence, the swimming path. To cope with the panoply of challenges to reach and fertilize the egg, sperm from different species have developed their own unique repertoire of signaling molecules and mechanisms. Here, we review the differences and commonalities for sperm sensory signaling in marine invertebrates (sea urchin), fish (zebrafish), and mammals (mouse, human).

$S_{\mathrm{p}}^{\mathrm{p}}$ perm carry a motile hair-like protrusioncalled flagellum-that extends from the head. The flagellum serves both as sensory antenna and propelling motor. Sperm flagella and motile cilia share a similar $9+2$ axoneme structure. The sperm cell is propelled by bending waves traveling down the flagellum. For steering, sperm modulate the asymmetry of the flagellar waveform. Sperm motility has been mostly studied in two dimensions (2D) at the glass/water interface of shallow observation chambers (Böhmer et al. 2005; Alvarez et al. 2012). When the flagellum beats symmetrical with respect to the long axis of the ellipsoid-shaped head, sperm move on a straight path; when the flagellum beats more asymmetrical, the swimming path is curved. If unrestricted, sperm from several species swim on helical paths or chiral ribbons (Crenshaw 1990, 1993a,b; Crenshaw and Edelstein-Keshet 1993; Corkidi et al. 2008; Su et al. 2012; Jikeli et al. 2015).

Various chemical and physical cues guide sperm to the egg. Quite generally, these cues enable signaling pathways that ultimately evoke a cellular $\mathrm{Ca}^{2+}$ response that in turn modulates the waveform of the flagellar beat and hence the swimming path (Böhmer et al. 2005; Wood et al. 2005; Shiba et al. 2008). Four different mechanisms have been identified that guide sperm to the egg: chemotaxis, haptotaxis, thermotaxis, and rheotaxis (Box 1).

Chemotaxis has been firmly established in marine invertebrates, notably in sperm from the sea urchin Arbacia punctulata (Fig. 1A). The

Editors: Wallace Marshall and Renata Basto

Additional Perspectives on Cilia available at www.cshperspectives.org

Copyright (C) 2017 Cold Spring Harbor Laboratory Press; all rights reserved; doi: 10.1101/cshperspect.a028225

Cite this article as Cold Spring Harb Perspect Biol 2016;9:a028225 
D. Wachten et al.

\section{BOX 1}

Chemotaxis refers to directed movement of cells in a gradient of a chemical substance. When sperm probe a chemical gradient along a circular or helical path, the spatial gradient is translated into a temporal stimulus pattern, which elicits periodic steering responses. This stimulus pattern is composed of a fast periodic component, which results from the helical or circular swimming path, and a mean stimulus component that increases or decreases when swimming up or down the gradient, respectively. During 3D navigation, the torsion of the helical 3D path is in phase $\left(\varphi=0^{\circ}\right)$ and the path curvature is in antiphase $\left(\varphi=180^{\circ}\right)$ with respect to the fast periodic stimulus component; the helix continuously bends to align with the attractant gradient ("on response"). If sperm happen to swim down the gradient, the mean stimulus level decreases and sperm respond with a strong correcting turn toward higher attractant concentrations ("off response") (Jikeli et al. 2015).

Rheotaxis refers to the directed movement of cells against a fluid flow. It is a mechanical sense because cells register a gradient of flow velocities. Because freely swimming sperm rotate around the longitudinal axis of the flagellum, mouse sperm are exposed to different flow velocities along their length.

Haptotaxis refers to the directed movement of cells on a surface that is covered with tethered chemoattractant molecules that form a chemical density gradient. Haptotaxis could occur on the surface of fish eggs and the epithelial layer of the fallopian tube.

Thermotaxis refers to directed movement in a temperature gradient. In one concept, sperm "tumble" by hyperactivation followed by straighter and faster swimming periods up the temperature gradient, similar to the tumble-and-run mechanism of bacteria during chemotaxis.

corresponding chemoattractant and the sequence of signaling events have been identified. The signaling pathway endows Arbacia sperm with exquisite sensitivity: they can register binding of a single chemoattractant molecule and transduce this event into a cellular $\mathrm{Ca}^{2+}$ response. Moreover, the navigation strategy in 2D and 3D chemoattractant gradients has been deciphered (Böhmer et al. 2005; Alvarez et al. 2012; Jikeli et al. 2015). In a 2D gradient, sperm swim on looping trajectories; in a 3D gradient, the swimming helix bends to align with the gradient (Jikeli et al. 2015).

Sperm of teleost fish are not actively attracted to the egg from afar (Yanagimachi et al. 2013). Instead, male fish deposit sperm directly onto the egg surface. Hydrodynamic interactions provide a theoretical framework that explains why sperm accumulate at interfaces (Rothschild 1963; Winet et al. 1984; Cosson et al. 2003), follow boundaries in microchannels, or for that matter stay at the egg surface (Elgeti and Gompper 2009; Lauga and Powers 2009; Elgeti et al. 2010; Denissenko et al. 2012). For fertilization, fish sperm must search for the narrow entrance to a cone-shaped funnel in the egg coat-the micropyle-that provides access to the egg membrane for fusion (Fig. 1B) (Yanagimachi et al. 2013). Sperm reach the micropyle probably by haptic interactions with tethered molecules that line the egg surface and the opening or interior of the micropyle. Thus, fish sperm motility might be governed by specific hydrodynamic and haptic interactions with the egg surface and the micropyle.

In mammals, chemotaxis, rheotaxis, and thermotaxis have been proposed as guiding mechanisms (Bretherton and Rothschild 1961; Bahat et al. 2003, 2012; Eisenbach and Giojalas 2006; Miki and Clapham 2013; Kantsler et al. 2014; Boryshpolets et al. 2015; Bukatin et al. 2015; Perez-Cerezales et al. 2015; Zhang et al. 2016). Neither one of these mechanisms nor their respective contribution to sperm guidance across the long and narrow oviduct is well understood (Fig. 1C). This ignorance is a result of the technical difficulties to emulate the complex native conditions encountered by mammalian sperm during fertilization. On their journey to the egg, mammalian sperm undergo two processes-capacitation and hyperactivation-necessary to acquire the potential 

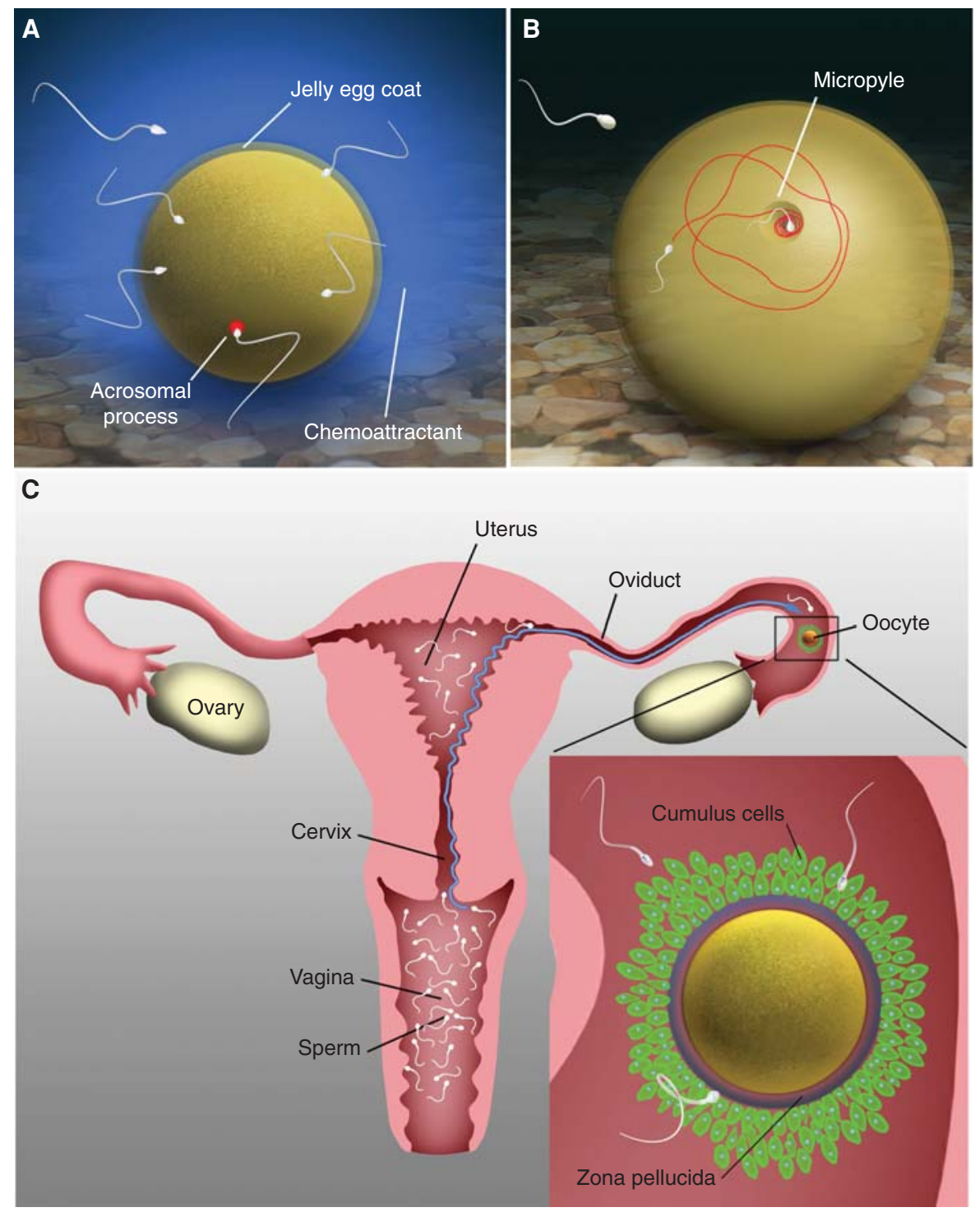

Figure 1. Fertilization in marine invertebrates, fish, and mammals. (A) In many marine invertebrates, sperm are attracted by chemotaxis (blue gradient); sperm can elicit the acrosomal process and fertilize the egg at any site of the egg surface. $(B)$ Fish sperm are probably not attracted from afar by chemoattractants. Instead, sperm navigate on the egg surface to a small opening, the micropyle. The mechanisms and molecules underlying directed movement on the egg surface are not known. (C) Mammalian sperm are guided by several mechanisms across the female genital tract. The specifics and underlying molecules are discussed.

to fertilize the egg (Suarez et al. 1993; Suarez 2008). At any given time, only a small fraction of sperm is capacitated or hyperactive; therefore, mammalian sperm populations are heterogeneous. Moreover, mammalian sperm are spatially constrained in the convoluted female reproductive tract and interact with the ciliated epithelial layer that lines the oviduct. Notwithstanding this complexity, major advances have been achieved identifying the signaling molecules and delineating the signaling events that encode $\mathrm{Ca}^{2+}$ responses. 
D. Wachten et al.

In this review, we discuss what is known about signaling pathways that control sperm sensory signaling in sea urchin, zebrafish, and in mammals.

\section{SIGNALING IN SEA URCHIN SPERM AND OTHER MARINE INVERTEBRATES}

\section{Overview}

Oocytes from the sea urchin A. punctulata release a short, species-specific chemoattractant peptide (resact, 14 amino acids in length). The chemoattractant binds to a receptor guanylate cyclase (GC) and thereby stimulates the synthesis of cGMP (Fig. 2A). In turn, cGMP opens $\mathrm{K}^{+}$-selective cyclic nucleotide-gated (CNGK) channels. The ensuing hyperpolarization-the resting potential $V_{\text {rest }}$ is $\sim-50 \mathrm{mV}$-activates two other signaling components: a voltage-gated sodium/proton exchanger (sNHE) and a hyperpolarization-activated, cyclic nucleotidegated $(\mathrm{HCN})$ channel. sNHE activity causes a small intracellular alkalization that shifts the voltage dependence of the sperm-specific $\mathrm{Ca}^{2+}$ channel (CatSper, cation channel of sperm) to more negative values and thereby "primes" CatSper to open during the return of $V_{m}$ to resting value. This return is initiated by the HCN channel that carries an $\mathrm{Na}^{+}$inward current. Recovery from the $\mathrm{Ca}^{2+}$ response is accomplished by a sodium/calcium/potassium exchanger (NCKX) and a plasma membrane $\mathrm{Ca}^{2+}$-ATPase (PMCA) that restore $\mathrm{Ca}^{2+}$ levels, and a phosphodiesterase (PDE) that breaks down cGMP.

How common is this chemotactic signaling pathway? Sperm of the sea urchin Strongylocentrotus purpuratus harbor a similar cGMP-signaling pathway; however, in shallow recording chambers frequently used for the study of chemotactic behavior under the microscope, S. purpuratus sperm do not display chemotaxis (Guerrero et al. 2010). Presumably, the geometric conditions under which $2 \mathrm{D}$ chemotaxis can be observed are severely restricted for S. purpuratus sperm. Sperm of the sea star Asterias amurensis also use a peptide as chemoattractant, a GC as chemoreceptor (Nishigaki et al. 1996; Matsumoto et al. 2003), and binding of the chemoattractant elicits a rapid transient increase of cGMP that evokes a $\mathrm{Ca}^{2+}$ response (Matsumoto et al. 2003). Arbacia and Strongylocentrotus diverged 200 million years ago, whereas the split between asteroids (seastars) and echinoids (sea urchins) occurred approximately 500 million years ago. Thus, the cGMPsignaling pathway has been conserved for at least 500 million years in many marine invertebrates across several phyla. In the following, the signaling components are discussed in more detail.

\section{THE CHEMORECEPTOR GUANYLATE CYCLASE}

The chemoreceptor GC is composed of three functional domains (Potter 2011): an extracellular domain binds the chemoattractant peptide resact, an intracellular catalytic domain synthesizes cGMP, and a single transmembrane domain connects the binding and catalytic domain and relays the binding event to the cell interior (Fig. 2A). The oligomeric structure of the GC is not known. Mammalian orthologs exist either as dimers or trimers (Wilson and Chinkers 1995; Yu et al. 1999; Vaandrager 2002; Ogawa et al. 2004). The overall chemotactic sensitivity relies on a high efficacy to capture the chemoattractant; the efficacy is maximal if every molecule that hits the flagellum binds to a receptor and activates it. The receptor density and affinity determine the capture efficacy. The flagellum harbors about 300,000 GC copies at a density of 9500 GC molecules $/ \mu \mathrm{m}^{2}$ (Pichlo et al. 2014). In fact, the GC rivals with rhodopsin in photoreceptors $(\sim 26,000-45,000$ rhodopsin molecules $/ \mu \mathrm{m}^{2}$ ) as one of the most densely packed membrane receptors (Fotiadis et al. 2003; Gunkel et al. 2015). At very low receptor occupancy, the binding affinity of the GC is in the picomolar range $\left(K_{1 / 2}=90 \mathrm{pM}\right)$. Thus, high capture efficacy is achieved by combining an extraordinary high GC density and ligand affinity. At higher occupancy, the GC affinity is lower $\left(K_{1 / 2}=0.65 \mathrm{nM}\right)$. In fact, chemoattractant binding spans six orders of magnitude; the broad operational range might involve negative cooperation among GC subunits, a negative cellular feedback, or a combination of both. The affinity adjustment ensures that, at high chemo- 


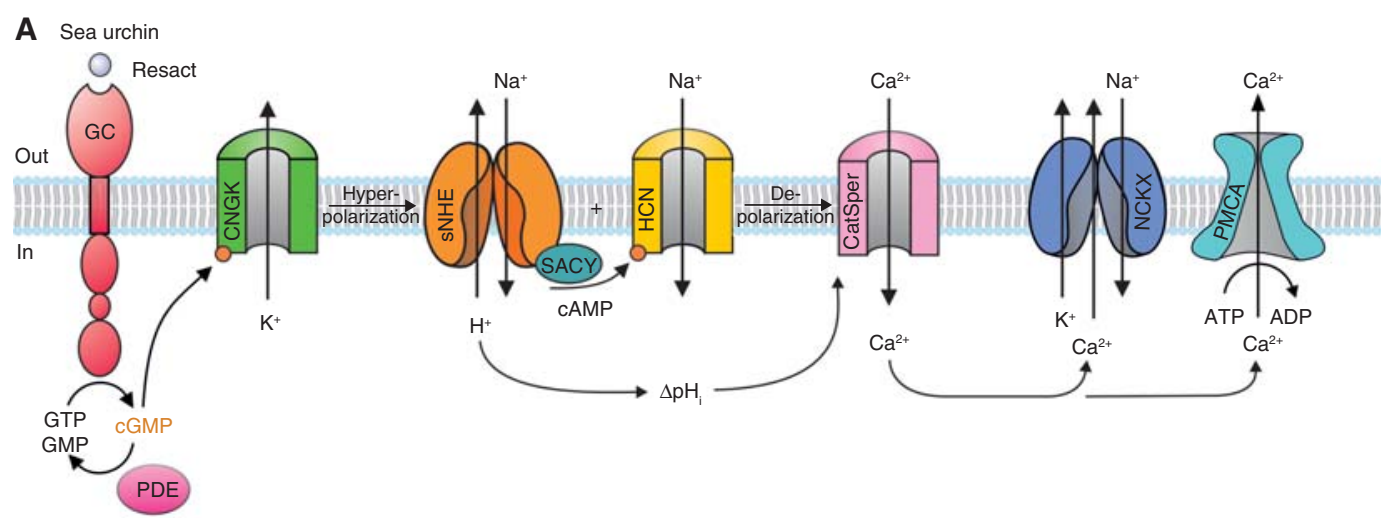

B

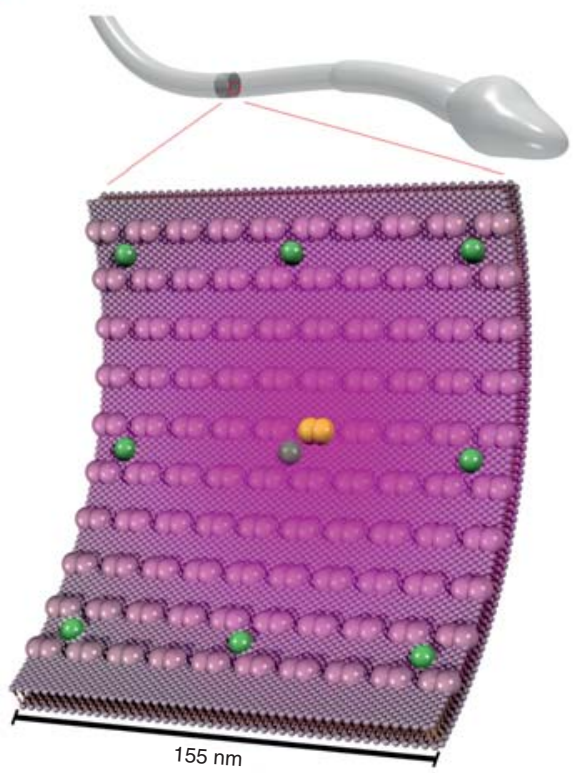

Figure 2. Signaling pathway in sea urchin sperm. (A) The guanylate cyclase (GC) serves as the receptor for the chemoattractant resact. Resact binding activates the GC, resulting in cGMP synthesis. cGMP activates the $\mathrm{K}^{+}$selective cyclic nucleotide-gated channel (CNGK). Opening of CNGK hyperpolarizes the cell and activates a hyperpolarization-activated and cyclic nucleotide-gated (HCN) channel and a sperm-specific voltage-dependent $\mathrm{Na}^{+} / \mathrm{H}^{+}$exchanger (sNHE). Opening of $\mathrm{HCN}$ channels restores the resting potential, whereas activation of sNHE increases the intracellular $\mathrm{pH}$. Both events activate the principal $\mathrm{Ca}^{2+}$ channel CatSper, leading to a $\mathrm{Ca}^{2+}$ influx. The $\mathrm{Ca}^{2+}$ levels are restored by $\mathrm{Ca}^{2+}$ extrusion through a Na${ }^{+} / \mathrm{Ca}^{2+} / \mathrm{K}^{+}$exchanger (NCKX) and a Ca ${ }^{2+}$ ATPase PMCA, whereas cGMP is hydrolyzed by a phosphodiesterase (PDE). On resact binding, sea urchin sperm not only synthesize cGMP, but also cAMP, probably through activation of the soluble adenylate cyclase (SACY), which, at least in mouse sperm, forms a complex with sNHE. One known target for cAMP is the HCN channel, whose voltage-dependent opening is modulated by cAMP. (B) Schematic distribution of GC receptors and CNGK channel on the flagellum. The GC (gray) and CNGK (green) densities are drawn to scale (ratio GC dimer/CNGK is 10:1). The cGMP gradient is depicted in shades of magenta. 
D. Wachten et al.

attractant concentrations prevailing near the egg, vacant receptors are still available.

The turnover number of active $\mathrm{GC}\left(\mathrm{GC}^{*}\right)$ is 72 cGMP molecules/GC* / second (Pichlo et al. 2014). GC* activity ceases within $150 \mathrm{~ms}$ probably by autodephosphorylation: at rest, six conserved serine residues carry phosphate groups that are removed on chemoattractant binding (Pichlo et al. 2014). GC* inactivation by multistage autodephosphorylation might allow for precise lifetime control, which could produce uniform $\mathrm{Ca}^{2+}$ responses and thereby reduce "molecule noise," which limits the precision of gradient sensing. A precedent for such a mechanism is the visual pigment rhodopsin: stepwise inactivation by two phosphorylation reactions and "capping" of phosphorylated rhodopsin by arrestin, a stop protein, has been proposed to control its lifetime and thereby reduce photon noise (Whitlock and Lamb 1999; Mendez et al. 2000; Doan et al. 2006). However, uniform single-photon responses also involve other mechanisms (Bisegna et al. 2008; Caruso et al. 2011; Gross et al. 2012a,b).

\section{THE CYCLIC NUCLEOTIDE-GATED $\mathrm{K}^{+}$CHANNEL}

The first electrical event in sea urchin sperm is a chemoattractant-induced hyperpolarization mediated by a cyclic nucleotide-gated $\mathrm{K}^{+}$channel (CNGK). The CNGK is unique compared with classic CNG channels (Bönigk et al. 2009; Cukkemane et al. 2011). Like voltage-activated $\mathrm{Ca}_{\mathrm{v}}$ and $\mathrm{Na}_{\mathrm{v}}$ channels, the large pore-forming polypeptide consists of four homologous repeats; each repeat carries the prototypical GYGD pore motif of $\mathrm{K}^{+}$channels and a cyclic nucleotide-binding domain (CNBD). The CNGK channel can respond to small changes in cGMP, because it is exquisitely sensitive to $\operatorname{cGMP}\left(K_{1 / 2}=20 \mathrm{nM}\right)$ and is activated in a noncooperative fashion. Disabling each of the four CNBDs through mutagenesis revealed that binding of a single cGMP molecule to the third repeat is necessary and sufficient to activate the channel (Bönigk et al. 2009). The other three CNBD domains either do not bind cGMP or fail to gate the channel pore. Thus, CNGK has developed a noncooperative mechanism of activation that is different from the activation of CNG channels in photoreceptors and olfactory neurons that require the cooperative binding of several ligands (Biskup et al. 2007) and that operate in the micromolar rather than the nanomolar range of cAMP or cGMP concentrations (Kaupp and Seifert 2002).

\section{A SPERM-SPECIFIC SODIUM/PROTON EXCHANGER (sNHE)}

Perhaps one of the most enigmatic signaling events is a sodium/proton exchange. As little as we know, in sea urchin sperm, exchange of $\mathrm{Na}^{+}$against $\mathrm{H}^{+}$is electroneutral and its activity is controlled by voltage (Lee 1984a,b, 1985; Lee and Garbers 1986). The exchange is thought to be catalyzed by members of a sperm-specific subfamily of solute carriers (SLC9C1 or sNHE) that are structurally unique. They share with other NHEs a membrane-spanning exchange domain that features at least 12 transmembrane segments (Wang et al. 2003). Unlike any other SLC family members, sNHE harbors a voltagesensor domain (VSD) similar to voltage-gated $\mathrm{K}^{+}-, \mathrm{Na}^{+}-$, and $\mathrm{Ca}^{2+}$ channels. Moreover, sNHE carry a CNBD similar to those in CNG and HCN channels. The presence of a VSD and a CNBD domain is both intriguing and presumably meaningful. However, sNHE molecules have not been functionally expressed. Therefore, the functions of these domains are unknown, even more so as some channels that harbor a VSD are not gated by voltage (e.g., CNG channels) and some CNG channels are not gated by cyclic nucleotides (Brelidze et al. 2013; Carlson et al. 2013; Haitin et al. 2013; Fechner et al. 2015). Considering the exquisite $\mathrm{pH}$ sensitivity of several signaling molecules, $\mathrm{pH}_{\mathrm{i}}$ homeostasis by sodium/proton exchange is an important research area for future work.

\section{HCN CHANNEL}

Two HCN channel isoforms, SpHCN1 and SpHCN2, have been identified in S. purpuratus (Gauss et al. 1998; Galindo et al. 2005). SpHCN1 (originally called SpIH) (Gauss et al. 1998) has been functionally characterized in a 
mammalian cell line bathed in normal Ringer solution. The ionic strength and composition of seawater and Ringer solution are entirely different. Moreover, whether the two orthologs form heteromers is not known. Thus, the physiological properties of the native $\mathrm{HCN}$ channel might be distinctively different from those of heterologously expressed SpHCN1. Notwithstanding, $S p H C N 1$ shares several basic properties with mammalian HCN channels in neurons and the heart. HCN channels become activated when the membrane is hyperpolarized (i.e., at $V_{m}$ more negative than $\sim 0 \mathrm{mV}$ ); their activity is enhanced by cAMP; and their permeability is three- to fourfold larger for $\mathrm{K}^{+}$than for $\mathrm{Na}^{+}$ ions. Therefore, under physiological conditions $\left(V_{m}>-30 \mathrm{mV}\right.$; high $\mathrm{Na}^{+}$outside, high $\mathrm{K}^{+}$ inside), HCN channels carry a depolarizing inward $\mathrm{Na}^{+}$current.

HCN channels may serve multiple functions in sea urchin sperm. First, they probably contribute to the unusually low $V_{\text {rest }}$ together with another ion channel with different ion selectivity (Fig. 3). There is a precedent in rod photoreceptors, which hyperpolarize on light stimulation. Two channels set $V_{\text {rest }}(-40 \mathrm{mV})$ : a $\mathrm{K}^{+}$channel in the inner segment (reversal potential $V_{\text {rev }}=-75 \mathrm{mV}$ ) and a nonselective

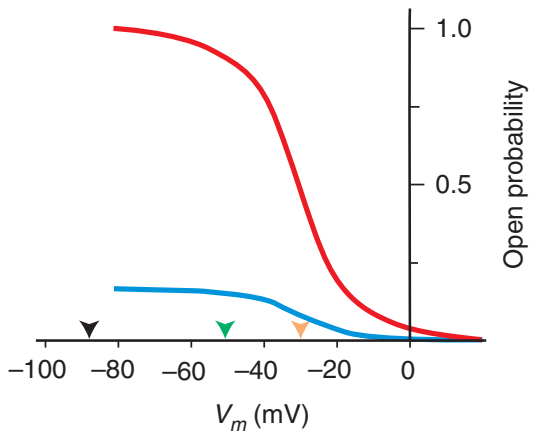

Figure 3. Membrane potential. The resting potential $V_{\text {rest }}$ of $\sim-50 \mathrm{mV}$ (green arrowhead) is probably determined by the hyperpolarization and cyclic nucleotide-gated $(\mathrm{HCN})$ channels $\left(V_{\text {rev }} \sim-30 \mathrm{mV}\right.$ in Ringer solution, orange arrowhead) and the $\mathrm{K}^{+}$-selective cyclic nucleotide-gated (CNGK) channel ( $V_{\text {rev }}$ $9 \sim-0 \mathrm{mV}$, black arrowhead). The $\mathrm{V}_{1 / 2}$ of $\mathrm{HCN}$ opening is similar with and without cAMP, whereas open probability $\mathrm{P}_{\mathrm{o}}$ is much larger in the presence of cAMP (red) than without (blue).
CNG channel in the outer segment $\left(V_{\text {rev }}=\right.$ $0 \mathrm{mV})$. In sperm, the HCN channel $\left(V_{\text {rev }}=\right.$ $-30 \mathrm{mV}$ in Ringer solution) and the CNGK channel $\left(V_{\text {rev }}=-90 \mathrm{mV}\right)$ or another $\mathrm{K}^{+}$channel could set $V_{\text {rest }}$ at $\sim-50 \mathrm{mV}$ (Fig. 3). In fact, a fraction of $S p H C N 1$ channels is constitutively open at rest (Gauss et al. 1998).

Second, $\mathrm{HCN}$ channels carry an inward $\mathrm{Na}^{+}$ current and thus counter the hyperpolarization. In retinal rods, HCN channels also repolarize the cell quickly in bright light and prevent $V_{m}$ from reaching the $\mathrm{K}^{+}$equilibrium potential $E_{K}$. $\mathrm{HCN}$ channels in sperm are likely to serve a similar function: they initiate the rapid recovery from stimulation and allow sperm to encode a wide range of chemoattractant concentrations.

Third, sperm HCN channels are set apart from their mammalian cousins by two unique properties. $S p H C N 1$, after a hyperpolarizing voltage step, first activates and then inactivates. cAMP removes the inactivation and consequently enhances the open probability $\mathrm{P}_{\mathrm{o}}$ (Fig. 3). In contrast, mammalian $\mathrm{HCN}$ channels do not inactivate and cAMP shifts the $\mathrm{P}_{\mathrm{o}}-V_{m}$ relation to less negative potentials without affecting much the maximal current. Because of the exquisite cAMP sensitivity $\left(K_{1 / 2}=0.75 \mu \mathrm{M}\right)$ and the large effect of cAMP on $\mathrm{P}_{\mathrm{o}}$, modulation of sperm HCN channels by cAMP might control the sensitivity of sperm, that is, contribute to adaptation.

Finally, HCN channels are often referred to as pacemakers, because they control rhythmic electrical activity in neurons and cardiac myocytes. HCN channels may serve a similar function in sperm. The periodic swimming path temporally organizes the stimulus pattern that is perceived by sperm. The ensuing periodic stimulation pattern entrains $\mathrm{Ca}^{2+}$ oscillations (Böhmer et al. 2005). Future studies need to examine whether HCN channels are important for pacing $\mathrm{Ca}^{2+}$ oscillations in sperm.

\section{CatSper CHANNEL}

CatSper is one of the most complex voltagegated ion channels. Like in mammalian sperm, the CatSper channel in A. punctulata comprises four homologous $\alpha$ subunits (CatSper 1-4) 
D. Wachten et al.

and at least three auxiliary subunits: CatSper $\beta$, CatSper $\gamma$, and CatSper $\delta$ (Seifert et al. 2015). At rest, CatSper is closed and is activated by a "switch-like" mechanism that involves two steps. The alkalization by sNHE shifts the voltage dependence to more negative values; the $\mathrm{pH}$ dependence of this cooperative shift is exceptionally steep (Hill coefficient of about 11) (Seifert et al. 2015). During recovery from hyperpolarization, CatSper opens (Fig. 2A). The high cooperativity permits CatSper to transduce the minute elementary changes in $\mathrm{pH}_{\mathrm{i}}$ and $V_{m}$ into a $\mathrm{Ca}^{2+}$ response.

\section{ADENYLATE CYCLASE AND CAMP - IN SEARCH OF A FUNCTION}

In contrast to cGMP, much less is known about the regulation and function of cAMP. Stimulation with resact evokes a rise of cAMP that is delayed with respect to the increase of cGMP (Kaupp et al. 2003). The synthesis of cAMP, presumably by a soluble adenylate cyclase (SACY) (Nomura et al. 2005), is enhanced under hyperpolarizing conditions (Beltrán et al. 1996) and alkaline $\mathrm{pH}_{\mathrm{i}}$ (Cook and Babcock 1993), but is insensitive to $\mathrm{Ca}^{2+}$ (Nomura et al. 2005). Each of these properties is at odds with those of other SACYs, which are activated by bicarbonate and $\mathrm{Ca}^{2+}$ (Chen et al. 2000; Jaiswal and Conti 2003; Steegborn et al. 2005; Kleinboelting et al. 2014). Either the SACY in sperm of sea urchin mammals are entirely different, or a different membrane-spanning $\mathrm{AC}$ is involved in sea urchins. Protein kinase A (PKA) in mammalian sperm represents a sperm-specific isoform that is different from that in somatic cells (Nolan et al. 2004; Burton and McKnight 2007).

\section{MOLECULES FOR RECOVERY}

Although the signaling events that excite sea urchin sperm have been delineated in great detail, much less is known about recovery and adaptation. For recovery from chemoattractant stimulation cGMP, cAMP, $\mathrm{pH}_{\mathrm{i}},\left[\mathrm{Ca}^{2+}\right]_{\mathrm{i}}$, and $V_{m}$ must return to baseline levels. The elevated cGMP level is probably lowered by a cGMP-specific PDE 5 (Su and Vacquier 2006). The mole- cules that reestablish resting $\mathrm{pH}_{\mathrm{i}}$ are not known. $\mathrm{Ca}^{2+}$ levels return to baseline owing to the activity of a sodium/calcium/potassium exchanger (NCKX) (Su and Vacquier 2002), and a $\mathrm{Ca}^{2+}$-ATPase in the plasma membrane (PMCA) (Gunaratne et al. 2006). How these molecules are regulated is not known (Fig. 2A).

\section{SINGLE-MOLECULE SENSITIVITY BY THE NUMBERS}

Several mechanisms have been proposed that explain ultrasensitivity in cells. These concepts largely originate from the study of signaling in photoreceptors, olfactory neurons, and bacteria. Mechanisms include (1) lattices of highly cooperative chemoreceptors in bacteria (Maddock and Shapiro 1993; Bray et al. 1998; Duke and Bray 1999; Gestwicki and Kiessling 2002; Sourjik and Berg 2004); (2) high multistage gain provided by a cascade of enzymatic reactions in photoreceptors (Pugh and Lamb 2000; Yau and Hardie 2009; Kaupp 2010); (3) local signaling by supramolecular complexes (transducisome or signalosome) (Huber et al. 1996; Tsunoda et al. 1997; Scott and Zuker 1998); and (4) restricted diffusion of chemical messengers in confined cellular subcompartments (Rich et al. 2000, 2001).

As will become clear, sperm use different mechanisms to achieve single-molecule sensitivity. First, sperm do not rely on arrays of receptor clusters that display positive cooperativity, although the GC may adopt a supramolecular organization that, however, serves other functions.

Second, amplification at the receptor level is orders of magnitude lower in sperm compared with rod photoreceptors. Rods also entertain a cGMP-signaling pathway that endows these cells with single-photon sensitivity. Capture of a photon initiates the hydrolysis of 2000 to 72,000 cGMP molecules, depending on the species, by two-stage amplification (Pugh and Lamb 2000; Burns and Pugh 2010; Arshavsky and Burns 2014). For sperm, a lower and upper limit of the number of cGMP molecules involved in single-molecule events has been estimated by two different methods. During its life- 
time, a GC* synthesizes $\sim 11$ cGMP molecules (Pichlo et al. 2014). Using fluorescent caged cGMP, the number of cGMP molecules required for a single-molecule response was estimated to be about 47 cGMP molecules (Bönigk et al. 2009). Both estimates are fraught with uncertainties. The turnover rate of cGMP synthesis was determined at relatively high chemoattractant concentrations and has been linearly extrapolated to the single-molecule regime. However, the catalytic turnover might depend on the occupation level of the GC. For example, if the GC exists as a dimer and if each subunit binds a resact molecule (stoichiometry 2:2), the turnover of single- or double-occupied receptors might be different. Finally, it is assumed that the concentration of membrane-permeant caged cGMP has completely equilibrated across the membrane. Apart from these uncertainties, cGMP amplification in rods is about 600 -fold larger than in sperm. Nonetheless, rod and sperm operate at a similar level of sensitivity: binding of a molecule to sperm or capture of a photon by rods each evokes a $\Delta V_{m}$ of 1-2 mV (Pugh and Lamb 2000; Strünker et al. 2006). Taking into account a volume ratio $V_{\text {rod }}$ $V_{\text {flagellum }}$ of $80 / 2 \mathrm{fl}=40: 1$, the change in cGMP concentration per unit volume is only $15 \times$ larger in rods compared with sperm.

Third, it has been argued that second-messenger concentrations steeply decay from the site of synthesis (Rich et al. 2000, 2001), which calls either for a signaling complex between receptors and downstream targets or for restricted diffusion in subcellular compartments channeling the messenger to the target. In order for a GC-CNGK complex to be effective, receptor (GC) and target (CNGK channel) ought to be present stoichiometrically, whereas, in fact, the GC is 24-fold more abundant than the CNGK (Pichlo et al. 2014). Thus, a "transducisome" between GC and CNGK is unlikely to contribute to single-molecule sensitivity of the sea urchin sperm.

The impact of cGMP diffusion from a point source at the membrane in a small cylindrical compartment like the flagellum was assessed (Pichlo et al. 2014). Within $\sim 15 \mu \mathrm{s}$, the cGMP concentration equilibrates across the fla- gellar diameter and, within $\sim 100 \mathrm{~ms}$, it equilibrates along the length of the flagellum. In a 155-nm-long segment of the flagellum, neglecting cGMP binding to high-affinity buffers or hydrolysis by PDEs, the cGMP transiently increases to micromolar concentrations that saturate any nearby CNGK channels $\left(K_{1 / 2}=\right.$ $26 \mathrm{nM}$ ) (Bönigk et al. 2009). For a regular arrangement of $\sim 100$ GC dimers in a $155 \times 155$ nm membrane patch, an active GC* $^{*}$ would be girded by nine CNGK channels at a distance not farther than $\sim 100 \mathrm{~nm}$ (Fig. $2 \mathrm{~B}$ ); these next neighbors would be first served with cGMP molecules. Finally, the input resistance of sperm ( $\gtrsim 5$ G $\Omega$ ) (Navarro et al. 2007; Zeng et al. 2013) is at least five-fold higher than that of mammalian rod photoreceptors (1-2 G $\Omega$ ) (Schneeweis and Schnapf 1995); thus, by changing the open probability of only a few CNGK channels, sperm can produce a single-molecule response.

In conclusion, there is no need to invoke high amplification, signaling complexes, or restricted diffusion to account for single-molecule sensitivity of sperm. The exquisite cGMP sensitivity of CNGK channels, the minuscule flagellar volume, and the high input resistance are key. A word of caution: all of these conclusions have been inferred from population measurements. Future work requires to study single-molecule sensitivity in single sperm cells. Notwithstanding, the hallmarks of this signaling mechanism might provide a blueprint for chemical sensing in small compartments such as olfactory cilia, insect antennae, or even synaptic boutons.

\section{SIGNALING IN FISH}

Navigation of fish sperm and the underlying signaling pathways must be arguably different from those of marine invertebrates and mammals. First, teleost fish lack CatSper channels (Cai and Clapham 2008). However, activation of sperm motility requires $\mathrm{Ca}^{2+}$ influx (Billard 1986; Takai and Morisawa 1995; Alavi and Cosson 2006; Cosson et al. 2008; Morisawa 2008). Motility is activated by hyper- or hypoosmotic shock after spawning of sperm into seawater or freshwater, respectively (Krasznai et al. 2000; Vines et al. 2002; Alavi and Cosson 2006; Cherr 
D. Wachten et al.

et al. 2008; Morisawa 2008). Therefore, $\mathrm{Ca}^{2+}$ influx in fish sperm involves other $\mathrm{Ca}^{2+}$ channels or $\mathrm{Ca}^{2+}$ release from intracellular stores.

Second, the ionic milieu seriously constrains ion channel function. Sperm of freshwater fish, marine invertebrates, and mammals are facing entirely different ionic milieus. $\mathrm{K}^{+}$and $\mathrm{Na}^{+}$concentrations in freshwater are extremely low (70 $\mu \mathrm{M}$ and $200 \mu \mathrm{M}$, respectively) compared with the orders-of-magnitude higher concentrations in seawater or the oviduct (Alavi and Cosson 2006; Hugentobler et al. 2007). Furthermore, $\left[\mathrm{Ca}^{2+}\right]$ in seawater is high $(10 \mathrm{mM})$, whereas in freshwater it is low $(<1 \mathrm{mM})$. The low salt concentrations in freshwater probably require ion channels that are differently designed. In fact, none of the ion channels controlling electrical and $\mathrm{Ca}^{2+}$ signaling of fish sperm had been known until recently.

Unexpectedly, although the principal targets of hyperpolarization-the sNHE and CatSper-are absent in fish, orthologs of the sperm CNGK channel are present in various fish genomes (Fig. 4) (Fechner et al. 2015). Surprisingly, the CNGK channel of zebrafish differs from its sea urchin cousin: it is activated by alkalinization, but not by cyclic nucleotides; moreover, the channel is localized in the head rather the flagellum; finally, the sea urchin CNGK is blocked by intracellular $\mathrm{Na}^{+}$, whereas the block of the zebrafish CNGK is much weaker. Future studies need to identify the molecules that are located upstream and downstream of CNGK in the signaling pathways in fish.

\section{MAMMALIAN SPERM-DIFFERENCES AND COMMONALITIES}

Mammalian sperm navigate across the female genital tract to reach the egg. During this transit, sperm undergo capacitation and hyperactivation. Capacitation is a complex, ill-defined maturation process. Hyperactivation is initiated during capacitation and is characterized by a whip-like beat of the flagellum, which is essential to penetrate the egg's vestments- the zona pellucida and cumulus cells (Suarez et al. 1993; Suarez 2008).

During their journey from the epididymis via the female genital tract to the egg, sperm experience an ever-changing environment, including large differences in $\mathrm{pH}$, ionic milieu, viscosity, and epithelial surfaces. To adapt to these changes, mammalian sperm have developed species-specific signaling mechanisms to reach and fertilize the egg. These differences are also reflected by large variations in sperm size and shape. Rodent sperm have a sickle-shaped head and a fairly long flagellum, whereas primate sperm feature an oval-shaped head and a shorter flagellum (Miller et al. 2015). In the following, differences and commonalities of sensory signaling between mouse and human sperm are described.

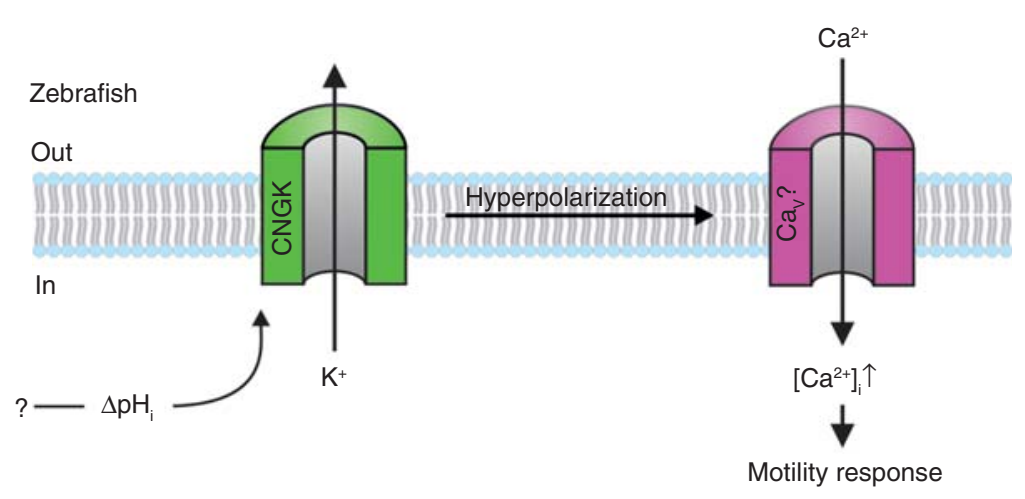

Figure 4. Signaling pathway in zebrafish. Only the $\mathrm{K}^{+}$-selective cyclic nucleotide-gated (CNGK) channel has been identified. The other components, in particular the $\mathrm{Ca}^{2+}$ channel, are not known. A change in $\mathrm{pH}_{\mathrm{i}}$ that is produced by unknown mechanisms upstream of CNGK causes hyperpolarization and, in turn, $\mathrm{Ca}^{2+}$ influx. 


\section{CatSper IS KEY FOR $\mathrm{Ca}^{2+}$ SIGNALING}

$\mathrm{Ca}^{2+}$ is also key for mammalian sperm navigation and fertilization: $\mathrm{Ca}^{2+}$ controls the flagellar beat pattern and, thus, sperm motility, navigation, rheotaxis, and hyperactivation. $\mathrm{Ca}^{2+}$ is also required for the acrosome reaction, which is needed to penetrate the egg's vestments and for capacitation.

Many different $\mathrm{Ca}^{2+}$ channels have been proposed to control sperm function (Darszon et al. 2011). Although some voltage-dependent $\mathrm{Ca}_{\mathrm{v}}$ channels might be present during spermatogenesis, CatSper has been identified as the principal $\mathrm{Ca}^{2+}$ channel in mature mammalian sperm (Fig. 5) (Lishko et al. 2012). CatSper forms a heteromeric channel complex made up of at least seven different subunits. Catsper1-4 ( $\alpha$-subunits) form the pore, whereas CatSper $\beta, \gamma$, and $\delta$ represent auxiliary subunits that are associated with the pore-forming complex (Ren et al. 2001; Carlson et al. 2003; Liu et al. 2007; Qi et al. 2007; Wang et al. 2009; Chung et al. 2011). Although basal motility is not affected by targeted disruption of CatSper subunits in mice, hyperactivation is abolished and capacitation is impaired (Carlson et al. 2003; Quill et al. 2003; Chung et al. 2014). Finally, rheotaxis is abolished in CatSper null sperm (Miki and Clapham 2013). Whether other potential navigation strategies like thermotaxis or chemotaxis also rely on CatSper is not known. However, a double knockout of CatSper and KSper conclusively shows that mouse sperm harbor no voltage and $\mathrm{pH}-\mathrm{de}$ pendent ion channels other than CatSper and KSper (Zeng et al. 2013). In line with the findings from mouse sperm, mutations in the human CatSper result in male infertility (Avidan et al. 2003; Zhang et al. 2007; Avenarius et al. 2009; Smith et al. 2013; Jaiswal et al. 2014).

CatSper serves as a platform along the flagellum to create signaling domains. CatSper channels form a quadrilateral arrangement in three dimensions that organizes structurally distinct $\mathrm{Ca}^{2+}$ signaling domains (Chung et al. 2014). Loss of any one of the CatSper channel subunits destroys the organization of these signaling domains and hyperactivated motility.
Furthermore, these $\mathrm{Ca}^{2+}$ domains also organize the spatiotemporal pattern of sperm capacitation (Chung et al. 2014).

The CatSper channel is a polymodal sensor that registers changes in membrane voltage, $\mathrm{pH}_{\mathrm{i}}$, and the concentration of various ligands. Mouse CatSper is less voltage-dependent than human CatSper, but shows a higher $\mathrm{pH}$ sensitivity (Kirichok et al. 2006; Lishko and Kirichok 2010; Lishko et al. 2011). At physiological $\mathrm{pH}_{\mathrm{i}}$ (7.4), the $V_{1 / 2}$ for human and mouse CatSper is $+85 \mathrm{mV}$ and $+11 \mathrm{mV}$, respectively (Lishko and Kirichok 2010; Lishko et al. 2011), indicating that at a resting membrane potential of $V_{\text {rest }}=$ $-30 \mathrm{mV}$, mouse CatSper would be partially open, whereas the human CatSper would be mostly closed.

In human sperm, the female sex hormone progesterone and prostaglandins in the oviductal fluid activate CatSper and cause a $\mathrm{Ca}^{2+}$ influx (Lishko et al. 2011; Strünker et al. 2011; Brenker et al. 2012). Progesterone has been proposed to act as a chemoattractant, controlling sperm navigation and fertilization (Teves et al. 2006; Oren-Benaroya et al. 2008). The CatSper activation occurs almost instantaneously and does not involve G-protein-coupled receptors (GPCRs) or G-proteins (Lishko et al. 2011; Strünker et al. 2011; Brenker et al. 2012), suggesting that CatSper is gated either directly by progesterone or a closely associated receptor. Recently, the orphan enzyme $\alpha / \beta$ hydrolase domain-containing protein 2 (ABHD2) has been identified as the progesterone receptor in human sperm (Fig. 5) (Miller et al. 2016). On progesterone binding, ABHD2 cleaves the endocannabinoids 1- and 2-arachidonoylglycerol (AGs) into free glycerol and arachidonic acid (Miller et al. 2016). AGs inhibit the CatSper current $\mathrm{I}_{\text {Catsper; }}$; however, hydrolysis of AGs by ABHD2 relieves their inhibition (Miller et al. 2016). Mouse sperm are insensitive to stimulation with progesterone. The species specificity of progesterone seems to be based on the difference in lipid homeostasis and localization of ABHD2 (Miller et al. 2016). In mouse sperm, ABHD2 is localized to the acrosome rather than the sperm flagellum (in contrast to human sperm). Thus, ABHD2 does not colocalize 
D. Wachten et al.
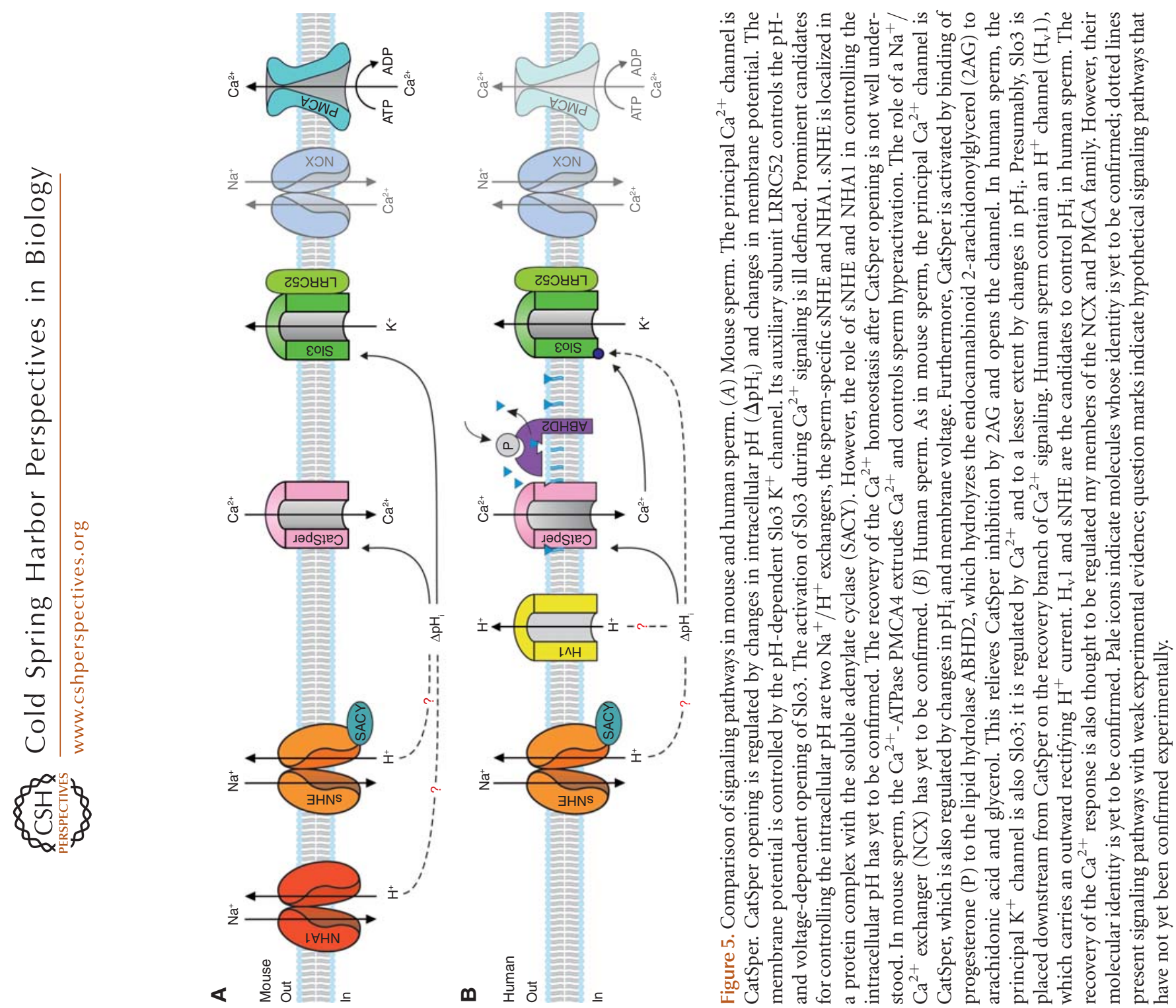
with CatSper. In addition, mouse sperm lose AGs during their transit through the epididymis; thus, CatSper is no longer inhibited by AGs and does not require progesterone-dependent hydrolysis of AGs for activation (Miller et al. 2016). In contrast, human sperm maintain high AG levels and require stimulation with progesterone for activation (Miller et al. 2016).

In addition to steroids and prostaglandins, other chemicals as diverse as odorants, menthol, and analogs of cyclic nucleotides, as well as various endocrine-disrupting chemicals (EDCs), can also activate CatSper (Brenker et al. 2012; Tavares et al. 2013; Schiffer et al. 2014). EDCs are omnipresent in food, household, and personal care products and have been linked to decreasing fertility rates in the Western world (Bergman et al. 2013). Whether these chemicals activate CatSper via ABHD2 or another mechanism is not known.

\section{$\mathrm{K}^{+}$CHANNELS AND THE CONTROL OF THE MEMBRANE POTENTIAL}

The principal $\mathrm{K}^{+}$channel in mouse sperm is Slo3, a member of the Slo family of ion channels (Schreiber et al. 1998; Santi et al. 2010; Zeng et al. 2011). Deletion of Slo3 severely impairs male fertility (Santi et al. 2010; Zeng et al. 2011). The Slo3 channel in mouse sperm is activated at $\mathrm{pH}_{\mathrm{i}}>6.0$ and membrane potentials $>0 \mathrm{mV}$ ( $\mathrm{pH} 7$ ); it carries a hyperpolarizing outward current (Navarro et al. 2007; Zeng et al. 2011). Apart from the pore-forming subunit encoded by the Slo3 gene, the channel complex also contains the auxiliary subunits LRRC52 and LRRC26 (leucine-rich repeat-containing proteins). LRRC52 regulates the $\mathrm{pH}$ - and voltage-dependent opening of the channel complex (Yang et al. 2011; Zeng et al. 2015). The development of hyperactivated motility during capacitation of mouse sperm is dependent on cytosolic alkalization followed by an increase of $\left[\mathrm{Ca}^{2+}\right]_{\mathrm{i}}$ (Suarez 2008). Slo3 mediates the hyperpolarization on alkalization (Zeng et al. 2011) and recent evidence suggests that hyperpolarization indirectly activates CatSper by promoting a rise of $\mathrm{pH}_{\mathrm{i}}$ through a voltage-dependent mechanism (Chavez et al. 2014). Together, Slo3 and CatSper are the sole ion channels in mouse sperm that regulate membrane potential and $\mathrm{Ca}^{2+}$ influx in response to alkalization (Zeng et al. 2013).

In contrast to mouse sperm, the $\mathrm{K}^{+}$current in human sperm is only weakly $\mathrm{pH}$-dependent, but strongly regulated by $\mathrm{Ca}^{2+}$ (Brenker et al. 2014). Consequently, the membrane potential in human sperm is sensitive to changes in $\mathrm{Ca}^{2+}$ and less so to $\mathrm{pH}_{\mathrm{i}}$. Furthermore, the $\mathrm{K}^{+}$current is inhibited by progesterone (Mannowetz et al. 2013; Brenker et al. 2014). Efforts to identify the molecules underlying the $\mathrm{K}^{+}$channel in human sperm provided mixed results. Initially, it was thought that Slo1, the $\mathrm{Ca}^{2+}$-regulated member of the Slo family carries the $\mathrm{K}^{+}$current in human sperm (Mannowetz et al. 2013). However, overwhelming evidence now shows that Slo1 is absent in human sperm and that a $\mathrm{Ca}^{2+}$-regulated Slo3 channel carries $\mathrm{K}^{+}$currents (Brenker et al. 2014). In particular, the properties of heterologously expressed human Slo3 match those of native $\mathrm{K}^{+}$currents, including block by quinidine and clofilium, inhibition by progesterone, modest $\mathrm{pH}$ sensitivity but large $\mathrm{Ca}^{2+}$-sensitivity, and single-channel conductance (70 pS) (Brenker et al. 2014). Thus, human sperm switched the ligand selectivity of Slo3 from $\mathrm{pH}_{\mathrm{i}}$ to $\mathrm{Ca}^{2+}$ rather than to adopt a new Slo isoform. Activation of the $\mathrm{Ca}^{2+}$-sensitive Slo3 might curtail $\mathrm{Ca}^{2+}$ influx via CatSper, suggesting that Slo3 in human sperm is placed downstream of CatSper on the recovery branch of $\mathrm{Ca}^{2+}$ signaling, whereas in mouse sperm, Slo3 at alkaline $\mathrm{pH}$ could hyperpolarize the cell and would open CatSper through a voltage-dependent alkalization.

\section{$\mathrm{Ca}^{2+}$ CLEARANCE MECHANISMS}

To restore $\mathrm{Ca}^{2+}$ levels, $\mathrm{Ca}^{2+}$ needs to be extruded from the cytoplasm or stored in intracellular organelles. In mouse sperm, the plasma membrane $\mathrm{Ca}^{2+}$-ATPase PMCA4 seems to be important to maintain $\mathrm{Ca}^{2+}$ homeostasis (Okunade et al. 2004; Schuh et al. 2004). PMCA4 null male mice are infertile and are unable to undergo hyperactivation. PMCA pumps are the fastest $\mathrm{Ca}^{2+}$ extrusion mechanisms in sperm. $\mathrm{Na}^{+} /$ $\mathrm{Ca}^{2+}$ exchanger (NCX) and mitochondrial 
D. Wachten et al.

$\mathrm{Ca}^{2+}$ uniporter are slower (Wennemuth et al. 2003a). However, the underlying molecules in mouse sperm are ill defined. In principal, similar $\mathrm{Ca}^{2+}$ clearance mechanisms also exist in human sperm. Future studies need to investigate the recovery branch of $\mathrm{Ca}^{2+}$ signaling in more detail.

\section{REGULATION OF $\mathrm{pH}_{\mathrm{i}}-$ ENIGMATIC IN MOUSE, BUT NOT SO MUCH IN HUMAN SPERM}

Changes in $\mathrm{pH}_{\mathrm{i}}$ control capacitation, hyperactivation, motility, and many signaling molecules are $\mathrm{pH}$-dependent. Several molecules have been proposed to control $\mathrm{pH}_{\mathrm{i}}$, including the voltagegated proton-specific channel $\mathrm{H}_{\mathrm{v}} 1$ (Lishko et al. 2010), different members of the protein family of solute carriers (SLC; sodium-proton exchangers and bicarbonate transporters), and carbonic anhydrases (Nishigaki et al. 2014).

In human sperm, the proton channel $\mathrm{H}_{\mathrm{v}} 1$ carries a large outwardly rectifying $\mathrm{H}^{+}$current (Lishko et al. 2010). The channel features unique characteristics: it is activated by membrane depolarization, regulated by $\mathrm{pH}_{\mathrm{i}}$ and $\mathrm{pH}_{\mathrm{o}}$, and inhibited by zinc (Ramsey et al. 2006; Sasaki et al. 2006). These characteristics may be particularly important during the transit through the female genital tract. When sperm are ejaculated, they are mixed with the seminal plasma that contains millimolar concentrations of zinc, rendering the channel inactive (Lishko and Kirichok 2010). During the transit through the female genital tract, zinc is chelated by proteins, suggesting that this causes a gradual activation of the channel (Lishko and Kirichok 2010). $H_{v} 1$ is also thought be activated by capacitation (Lishko et al. 2010). However, the underlying mechanism is still enigmatic.

In contrast to human sperm, mouse sperm do not contain an outwardly rectifying $\mathrm{H}^{+}$current and $\mathrm{H}_{\mathrm{v}} 1$ null male mice do not show a fertility defect (Miller et al. 2015). How the $\mathrm{pH}_{\mathrm{i}}$ is regulated in mouse sperm is not known. The most likely candidate has been an $\mathrm{Na}^{+} / \mathrm{H}^{+}$ exchanger specific for sperm (sNHE). Indeed, mice lacking sNHE are infertile because the sperm are immotile (Wang et al. 2003). Howev- er, sNHE is found in a complex with the SACY, the predominant source for cAMP in mammalian sperm (Wang et al. 2007). In fact, the loss of sNHE results in a concomitant loss of SACY. Thus, it is difficult to disentangle the physiological function of sNHE and the SACY. Cyclic AMP is essential for sperm development, motility, and maturation in the female genital tract (Visconti et al. 1995; Wennemuth et al. 2003b; Krähling et al. 2013). Mice lacking SACY are infertile and the sperm are immotile (Esposito et al. 2004). The motility defect in sNHE-null mice can be rescued by application of membrane permeable cAMP analogs or by optogenetic stimulation of cAMP production (Jansen et al. 2015), showing that the motility defect and thereby the infertile phenotype is solely due to the loss of SACY, but not sNHE (Wang et al. 2003). Recently, another NHE, NHA1, has been shown to control sperm function (Liu et al. 2010; Chen et al. 2016). However, information about its role in controlling $\mathrm{pH}_{\mathrm{i}}$ in mouse sperm is missing. Surprisingly, NHA1knockout mice also seem to display attenuated cAMP signaling and impaired sperm motility. Future studies need to reveal whether NHA1 regulates $\mathrm{pH}_{\mathrm{i}}$ in mouse sperm.

\section{SPERM COMPARTMENTALIZATION AND SUPRAMOLECULAR STRUCTURES}

Mammalian sperm show different levels of compartmentalization. The two major compartments are the head and the flagellum. The flagellum itself is separated into the midpiece, principal piece, and the endpiece, where signaling molecules and second messenger dynamics are spatially organized.

As described above, the CatSper complex creates structurally distinct $\mathrm{Ca}^{2+}$-signaling domains along the principal piece of mouse sperm (Chung et al. 2014). In human sperm, CatSper is also localized in the principal piece, and progesterone stimulation first elicits a $\mathrm{Ca}^{2+}$ increase in the principal piece and midpiece, which then propagates to the head (Servin-Vences et al. 2012). Furthermore, it has been shown that cAMP signaling pathways are compartmentalized in the head and flagellum (Wert- 
heimer et al. 2013) and that cAMP dynamics are also organized in distinct domains along the flagellum (Mukherjee et al. 2016). However, the molecular mechanisms underlying the compartmentalization of cAMP dynamics have not been identified yet. The combination of genetically encoded biosensors with optogenetics holds great promise to map the dynamics of cAMP signaling in live cells in precise spatiotemporal and quantitative terms.

\section{OUTLOOK}

Although many molecules in the flagellum of mammalian sperm have been identified that are involved in electrical and $\mathrm{Ca}^{2+}$ signaling, we do not know which sensory modality they serve: rheotaxis, chemotaxis, haptotaxis, or thermotaxis? In fact, other molecules, like rhodopsin, G-proteins, phospholipase C, TRPC3 channels, and $\mathrm{IP}_{3}$-gated channels have been implied in thermosensation of human sperm (Perez-Cerezales et al. 2015). Moreover, yet other molecules have been suggested for chemotaxis of human sperm in a progesterone gradient (Teves et al. 2009). Future work is required to unequivocally assign signaling pathways to behavioral responses during directed movement.

\section{ACKNOWLEDGMENTS}

We thank Dr. R. Pascal for preparing the figures and $\mathrm{H}$. Krause for preparing the manuscript.

\section{REFERENCES}

Alavi SM, Cosson J. 2006. Sperm motility in fishes. II: Effects of ions and osmolality: A review. Cell Biol Int 30: 1-14.

Alvarez L, Dai L, Friedrich BM, Kashikar ND, Gregor I, Pascal R, Kaupp UB. 2012. The rate of change in $\mathrm{Ca}^{2+}$ concentration controls sperm chemotaxis. J Cell Biol 196: 653-663.

Arshavsky VY, Burns ME. 2014. Current understanding of signal amplification in phototransduction. Cell Logist 4: e29390.

Avenarius MR, Hildebrand MS, Zhang Y, Meyer NC, Smith LL, Kahrizi K, Najmabadi H, Smith RJ. 2009. Human male infertility caused by mutations in the CATSPER 1 channel protein. Am J Hum Genet 84: 505-510.

Avidan N, Tamary H, Dgany O, Cattan D, Pariente A, Thulliez M, Borot N, Moati L, Barthelme A, Shalmon L, et al.
2003. CATSPER2, a human autosomal nonsyndromic male infertility gene. Eur J Hum Genet 11: 497-502.

Bahat A, Tur-Kaspa I, Gakamsky A, Giojalas LC, Breitbart H, Eisenbach M. 2003. Thermotaxis of mammalian sperm cells: A potential navigation mechanism in the female genital tract. Nat Med 9: 149-150.

Bahat A, Caplan SR, Eisenbach M. 2012. Thermotaxis of human sperm cells in extraordinarily shallow temperature gradients over a wide range. PLoS ONE 7: e41915.

Beltrán C, Zapata O, Darszon A. 1996. Membrane potential regulates sea urchin sperm adenylylcyclase. Biochemistry 35: 7591-7598.

Bergman A, Heindel JJ, Kasten T, Kidd KA, Jobling S, Neira M, Zoeller RT, Becher G, Bjerregaard P, Bornman R, et al. 2013. The impact of endocrine disruption: A consensus statement on the state of the science. Environ Health Perspect 121: A104-A106.

Billard R. 1986. Spermatogenesis and spermatology of some teleost fish species. Reprod Nutr Dev 26: 877-920.

Bisegna P, Caruso G, Andreucci D, Shen L, Gurevich VV, Hamm HE, DiBenedetto E. 2008. Diffusion of the second messengers in the cytoplasm acts as a variability suppressor of the single photon response in vertebrate phototransduction. Biophys J 94: 3363-3383.

Biskup C, Kusch J, Schulz E, Nache V, Schwede F, Lehmann F, Hagen V, Benndorf K. 2007. Relating ligand binding to activation gating in CNGA2 channels. Nature 446: $440-$ 443.

Böhmer M, Van Q, Weyand I, Hagen V, Beyermann M, Matsumoto M, Hoshi M, Hildebrand E, Kaupp UB. 2005. $\mathrm{Ca}^{2+}$ spikes in the flagellum control chemotactic behavior of sperm. EMBO J 24: 2741-2752.

Bönigk W, Loogen A, Seifert R, Kashikar N, Klemm C, Krause E, Hagen V, Kremmer E, Strünker T, Kaupp UB. 2009. An atypical CNG channel activated by a single cGMP molecule controls sperm chemotaxis. Sci Signal 2: ra68.

Boryshpolets S, Perez-Cerezales S, Eisenbach M. 2015. Behavioral mechanism of human sperm in thermotaxis: A role for hyperactivation. Hum Reprod 30: 884-892.

Bray D, Levin MD, Morton-Firth CJ. 1998. Receptor clustering as a cellular mechanism to control sensitivity. $\mathrm{Na}$ ture 393: 85-88.

Brelidze TI, Gianulis EC, DiMaio F, Trudeau MC, Zagotta WN. 2013. Structure of the C-terminal region of an ERG channel and functional implications. Proc Natl Acad Sci 110: $11648-11653$.

Brenker C, Goodwin N, Weyand I, Kashikar ND, Naruse M, Krähling M, Müller A, Kaupp UB, Strünker T. 2012. The CatSper channel: A polymodal chemosensor in human sperm. EMBO J 31: 1654-1665.

Brenker C, Zhou Y, Müller A, Echeverry FA, Trötschel C, Poetsch A, Xia XM, Bönigk W, Lingle CJ, Kaupp UB, et al. 2014. The $\mathrm{Ca}^{2+}$-activated $\mathrm{K}^{+}$current of human sperm is mediated by Slo3. eLife 3: e01438.

Bretherton FP, Rothschild. 1961. Rheotaxis of spermatozoa. Proc R Soc Lond B 2 153: 490-502.

Bukatin A, Kukhtevich I, Stoop N, Dunkel J, Kantsler V. 2015. Bimodal rheotactic behavior reflects flagellar beat asymmetry in human sperm cells. Proc Natl Acad Sci 112: 15904-15909. 
D. Wachten et al.

Burns ME, Pugh EN Jr. 2010. Lessons from photoreceptors: Turning off G-protein signaling in living cells. Physiology (Bethesda) 25: 72-84.

Burton KA, McKnight GS. 2007. PKA, germ cells, and fertility. Physiology (Bethesda) 22: 40-46.

Cai X, Clapham DE. 2008. Evolutionary genomics reveals lineage-specific gene loss and rapid evolution of a spermspecific ion channel complex: CatSpers and CatSper $\beta$. PLOS ONE 3: e3569.

Carlson AE, Westenbroek RE, Quill T, Ren D, Clapham DE, Hille B, Garbers DL, Babcock DF. 2003. CatSper1 required for evoked $\mathrm{Ca}^{2+}$ entry and control of flagellar function in sperm. Proc Natl Acad Sci 100: 14864-14868.

Carlson AE, Brelidze TI, Zagotta WN. 2013. Flavonoid regulation of EAG1 channels. J Gen Physiol 141: 347-358.

Caruso G, Bisegna P, Andreucci D, Lenoci L, Gurevich VV, Hamm HE, DiBenedetto E. 2011. Identification of key factors that reduce the variability of the single photon response. Proc Natl Acad 108: 7804-7807.

Chavez JC, Ferreira JJ, Butler A, De La Vega Beltran JL, Trevino CL, Darszon A, Salkoff L, Santi CM. 2014. SLO3 $\mathrm{K}^{+}$channels control calcium entry through CATSPER channels in sperm. J Biol Chem 289: 32266-32275.

Chen Y, Cann MJ, Litvin TN, Iourgenko V, Sinclair ML, Levin LR, Buck J. 2000. Soluble adenylyl cyclase as an evolutionarily conserved bicarbonate sensor. Science 289: 625-628.

Chen SR, Chen M, Deng SL, Hao XX, Wang XX, Liu YX. 2016. Sodium-hydrogen exchanger NHA1 and NHA2 control sperm motility and male fertility. Cell Death Dis 7: e2152.

Cherr GN, Morisawa M, Vines CA, Yoshida K, Smith EH, Matsubara T, Pillai MC, Griffin FJ, Yanagimachi R. 2008. Two egg-derived molecules in sperm motility initiation and fertilization in the Pacific herring (Clupea pallasi). Int J Dev Biol 52: 743-752.

Chung JJ, Navarro B, Krapivinsky G, Krapivinsky L, Clapham DE. 2011. A novel gene required for male fertility and functional CATSPER channel formation in spermatozoa. Nat Commun 2: 153.

Chung JJ, Shim SH, Everley RA, Gygi SP, Zhuang X, Clapham DE. 2014. Structurally distinct $\mathrm{Ca}^{2+}$ signaling domains of sperm flagella orchestrate tyrosine phosphorylation and motility. Cell 157: 808-822.

Cook SP, Babcock DF. 1993. Activation of $\mathrm{Ca}^{2+}$ permeability by cAMP is coordinated through the $\mathrm{pH}_{\mathrm{i}}$ increase induced by speract. J Biol Chem 268: 22408-22413.

Corkidi G, Taboada B, Wood CD, Guerrero A, Darszon A. 2008. Tracking sperm in three-dimensions. Biochem Biophys Res Commun 373: 125-129.

Cosson J, Huitorel P, Gagnon C. 2003. How spermatozoa come to be confined to surfaces. Cell Motil Cytoskel 54: $56-63$.

Cosson J, Groison AL, Suquet M, Fauvel C, Dreanno C, Billard R. 2008. Marine fish spermatozoa: Racing ephemeral swimmers. Reproduction 136: 277-294.

Crenshaw HC. 1990. Helical orientation-A novel mechanism for the orientation of microorganisms. In Biological motion (ed. Alt W, Hoffmann G), pp. 361-386. Springer, Berlin.
Crenshaw HC. 1993a. Orientation by helical motion. I: Kinematics of the helical motion of organisms with up to six degrees of freedom. Bull Math Biol 55: 197-212.

Crenshaw HC. 1993b. Orientation by helical motion. III: Microorganisms can orient to stimuli by changing the direction of their rotational velocity. Bull Math Biol 55: 231-255.

Crenshaw HC, Edelstein-Keshet L. 1993. Orientation by helical motion. II: Changing the direction of the axis of motion. Bull Math Biol 55: 213-230.

Cukkemane A, Seifert R, Kaupp UB. 2011. Cooperative and uncooperative cyclic-nucleotide-gated ion channels. Trends Biochem Sci 36: 55-64.

Darszon A, Nishigaki T, Beltran C, Trevino CL. 2011. Calcium channels in the development, maturation, and function of spermatozoa. Physiol Rev 91: 1305-1355.

Denissenko P, Kantsler V, Smith DJ, Kirkman-Brown J. 2012. Human spermatozoa migration in microchannels reveals boundary-following navigation. Proc Natl Acad Sci 109: 8007-8010.

Doan T, Mendez A, Detwiler PB, Chen J, Rieke F. 2006. Multiple phosphorylation sites confer reproducibility of the rod's single-photon responses. Science 313: 530-533.

Duke TAJ, Bray D. 1999. Heightened sensitivity of a lattice of membrane receptors. Proc Natl Acad Sci 96: 1010410108.

Eisenbach M, Giojalas LC. 2006. Sperm guidance in mammals-An unpaved road to the egg. Nat Rev Mol Cell Biol 7: 276-285.

Elgeti J, Gompper G. 2009. Self-propelled rods near surfaces Eur Phys Lett 85: 38002.

Elgeti J, Kaupp UB, Gompper G. 2010. Hydrodynamics of sperm cells near surfaces. Biophys J 99: 1018-1026.

Esposito G, Jaiswal BS, Xie F, Krajnc-Franken MAM, Robben TJAA, Strik AM, Kuil C, Philipsen RLA, van Duin M, Conti M, et al. 2004. Mice deficient for soluble adenylyl cyclase are infertile because of a severe sperm-motility defect. Proc Natl Acad Sci 101: 2993-2998.

Fechner S, Alvarez L, Bönigk W, Müller A, Berger T, Pascal R, Trötschel C, Poetsch A, Stolting G, Siegfried KR, et al. 2015. A K ${ }^{+}$-selective CNG channel orchestrates $\mathrm{Ca}^{2+}$ signalling in zebrafish sperm. eLife 4: e07624.

Fotiadis D, Liang Y, Filipek S, Saperstein DA, Engel A, Palczewski K. 2003. Rhodopsin dimers in native disc membranes. Nature 421: 127-128.

Galindo BE, Neill AT, Vacquier VD. 2005. A new hyperpolarization-activated, cyclic nucleotide-gated channel from sea urchin sperm flagella. Biochem Biophys Res Commun 334: 96-101.

Gauss R, Seifert R, Kaupp UB. 1998. Molecular identification of a hyperpolarization-activated channel in sea urchin sperm. Nature 393: 583-587.

Gestwicki JE, Kiessling LL. 2002. Inter-receptor communication through arrays of bacterial chemoreceptors. $\mathrm{Na}$ ture 415: 81-84.

Gross OP, Pugh EN Jr, Burns ME. 2012a. Calcium feedback to CGMP synthesis strongly attenuates single-photon responses driven by long rhodopsin lifetimes. Neuron 76: $370-382$. 
Gross OP, Pugh EN Jr, Burns ME. 2012b. Spatiotemporal cGMP dynamics in living mouse rods. Biophys J 102: $1775-1784$.

Guerrero A, Nishigaki T, Carneiro J, Yoshiro T, Wood CD, Darszon A. 2010. Tuning sperm chemotaxis by calcium burst timing. Dev Biol 344: 52-65.

Gunaratne HJ, Neill AT, Vacquier VD. 2006. Plasma membrane calcium ATPase is concentrated in the head of sea urchin spermatozoa. J Cell Physiol 207: 413-419.

Gunkel M, Schöneberg J, Alkhaldi W, Irsen S, Noe F, Kaupp UB, Al-Amoudi A. 2015. Higher-order architecture of rhodopsin in intact photoreceptors and its implication for phototransduction kinetics. Structure 23: 628-638.

Haitin Y, Carlson AE, Zagotta WN. 2013. The structural mechanism of KCNH-channel regulation by the eag domain. Nature 501: 444-448.

Huber A, Sander P, Gobert A, Bahner M, Hermann R, Paulsen R. 1996. The transient receptor potential protein (Trp), a putative store-operated $\mathrm{Ca}^{2+}$ channel essential for phosphoinositide-mediated photoreception, forms a signaling complex with NorpA, InaC and InaD. EMBO J 15: 7036-7045.

Hugentobler SA, Morris DG, Sreenan JM, Diskin MG. 2007. Ion concentrations in oviduct and uterine fluid and blood serum during the estrous cycle in the bovine. Theriogenology 68: 538-548.

Jaiswal BS, Conti M. 2003. Calcium regulation of the soluble adenylyl cyclase expressed in mammalian spermatozoa. Proc Natl Acad Sci 100: 10676-10681.

Jaiswal D, Singh V, Dwivedi US, Trivedi S, Singh K. 2014. Chromosome microarray analysis: A case report of infertile brothers with CATSPER gene deletion. Gene 542: 263-265.

Jansen V, Alvarez L, Balbach M, Strünker T, Hegemann P, Kaupp UB, Wachten D. 2015. Controlling fertilization and cAMP signaling in sperm by optogenetics. eLife 4: e05161.

Jikeli JF, Alvarez L, Friedrich BM, Wilson LG, Pascal R, Colin R, Pichlo M, Rennhack A, Brenker C, Kaupp UB. 2015. Sperm navigation along helical paths in 3D chemoattractant landscapes. Nat Commun 6: 7985.

Kantsler V, Dunkel J, Blayney M, Goldstein RE. 2014. Correction: Rheotaxis facilitates upstream navigation of mammalian sperm cells. eLife 3: e03521.

Kaupp UB. 2010. Olfactory signalling in vertebrates and insects: Differences and commonalities. Nat Rev Neurosci 11: $188-200$.

Kaupp UB, Seifert R. 2002. Cyclic nucleotide-gated ion channels. Physiol Rev 82: 769-824.

Kaupp UB, Solzin J, Hildebrand E, Brown JE, Helbig A, Hagen V, Beyermann M, Pampaloni F, Weyand I. 2003. The signal flow and motor response controlling chemotaxis of sea urchin sperm. Nat Cell Biol 5: 109-117.

Kirichok Y, Navarro B, Clapham DE. 2006. Whole-cell patch-clamp measurements of spermatozoa reveal an alkaline-activated $\mathrm{Ca}^{2+}$ channel. Nature 439: 737-740.

Kleinboelting S, Diaz A, Moniot S, van den Heuvel J, Weyand M, Levin LR, Buck J, Steegborn C. 2014. Crystal structures of human soluble adenylyl cyclase reveal mechanisms of catalysis and of its activation through bicarbonate. Proc Natl Acad Sci 111: 3727-3732.
Krähling AM, Alvarez L, Debowski K, Van Q, Gunkel M, Irsen S, Al-Amoudi A, Strünker T, Kremmer E, Krause E, et al. 2013. CRIS-A novel cAMP-binding protein controlling spermiogenesis and the development of flagellar bending. PLoS Genet 9: e1003960.

Krasznai Z, Márián T, Izumi H, Damjanovich S, Balkay L, Trón L, Morisawa M. 2000. Membrane hyperpolarization removes inactivation of $\mathrm{Ca}^{2+}$ channels, leading to $\mathrm{Ca}^{2+}$ influx and subsequent initiation of sperm motility in the common carp. Proc Natl Acad Sci 97: 2052-2057.

Lauga E, Powers TR. 2009. The hydrodynamics of swimming microorganisms. Rep Prog Phys 72: 096601.

Lee HC. 1984a. A membrane potential-sensitive $\mathrm{Na}^{+}-\mathrm{H}^{+}$ exchange system in flagella isolated from sea urchin spermatozoa. J Biol Chem 259: 15315-15319.

Lee HC. 1984b. Sodium and proton transport in flagella isolated from sea urchin spermatozoa. J Biol Chem 259: 4957-4963.

Lee HC. 1985. The voltage-sensitive $\mathrm{Na}^{+} / \mathrm{H}^{+}$exchange in sea urchin spermatozoa flagellar membrane vesicles studied with an entrapped $\mathrm{pH}$ probe. J Biol Chem 260: 10794-10799.

Lee HC, Garbers DL. 1986. Modulation of the voltage-sensitive $\mathrm{Na}^{+} / \mathrm{H}^{+}$exchange in sea urchin spermatozoa through membrane potential changes induced by the egg peptide speract. J Biol Chem 261: 16026-16032.

Lishko PV, Kirichok Y. 2010. The role of Hvl and CatSper channels in sperm activation. J Physiol 588: 4667-4672.

Lishko PV, Botchkina IL, Fedorenko A, Kirichok Y. 2010. Acid extrusion from human spermatozoa is mediated by flagellar voltage-gated proton channel. Cell 140: 327-337.

Lishko PV, Botchkina IL, Kirichok Y. 2011. Progesterone activates the principal $\mathrm{Ca}^{2+}$ channel of human sperm. Nature 471: 387-391.

Lishko PV, Kirichok Y, Ren D, Navarro B, Chung JJ, Clapham DE. 2012. The control of male fertility by spermatozoan ion channels. Annu Rev Physiol 74: 453-475.

Liu J, Xia J, Cho KH, Clapham DE, Ren D. 2007. CatSper $\beta$, a novel transmembrane protein in the CatSper channel complex. J Biol Chem 282: 18945-18952.

Liu T, Huang JC, Zuo WL, Lu CL, Chen M, Zhang XS, Li YC, Cai H, Zhou WL, Hu ZY, et al. 2010. A novel testis-specific $\mathrm{Na}^{+} / \mathrm{H}^{+}$exchanger is involved in sperm motility and fertility. Front Biosci (Elite Ed) 2: 566-581.

Maddock JR, Shapiro L. 1993. Polar location of the chemoreceptor complex in the Escherichia coli cell. Science 259: 1717-1723.

Mannowetz N, Naidoo NM, Choo SA, Smith JF, Lishko PV. 2013. Slo1 is the principal potassium channel of human spermatozoa. eLife 2: e01009.

Matsumoto M, Solzin J, Helbig A, Hagen V, Ueno S-I, Kawase O, Maruyama Y, Ogiso M, Godde M, Minakata H, et al. 2003. A sperm-activating peptide controls a cGMPsignaling pathway in starfish sperm. Dev Biol 260: 314324.

Mendez A, Burns ME, Roca A, Lem J, Wu L-W, Simon MI, Baylor DA, Chen J. 2000. Rapid and reproducible deactivation of rhodopsin requires multiple phosphorylation sites. Neuron 28: 153-164. 
D. Wachten et al.

Miki K, Clapham DE. 2013. Rheotaxis guides mammalian sperm. Curr Biol 23: 443-452.

Miller MR, Mansell SA, Meyers SA, Lishko PV. 2015. Flagellar ion channels of sperm: Similarities and differences between species. Cell Calcium 58: 105-113.

Miller MR, Mannowetz N, Iavarone AT, Safavi R, Gracheva EO, Smith JF, Hill RZ, Bautista DM, Kirichok Y, Lishko PV. 2016. Unconventional endocannabinoid signaling governs sperm activation via sex hormone progesterone. Science 352: 555-559.

Morisawa M. 2008. Adaptation and strategy for fertilization in the sperm of teleost fish. J Appl Ichthyol 24: 362-370.

Mukherjee S, Jansen V, Jikeli JF, Hamzeh H, Alvarez L, Dombrowski M, Balbach M, Strünker T, Seifert R, Kaupp UB, et al. 2016. A novel biosensor to study cAMP dynamics in cilia and flagella. eLife 5: e14052.

Navarro B, Kirichok Y, Clapham DE. 2007. KSper, a pHsensitive $\mathrm{K}^{+}$current that controls sperm membrane potential. Proc Natl Acad Sci 104: 7688-7692.

Nishigaki T, Chiba K, Miki W, Hoshi M. 1996. Structure and function of asterosaps, sperm-activating peptides from the jelly coat of starfish eggs. Zygote 4: 237-245.

Nishigaki T, Jose O, Gonzalez-Cota AL, Romero F, Trevino CL, Darszon A. 2014. Intracellular pH in sperm physiology. Biochem Biophys Res Commun 450: 1149-1158.

Nolan MA, Babcock DF, Wennemuth G, Brown W, Burton KA, McKnight GS. 2004. Sperm-specific protein kinase A catalytic subunit $\mathrm{C}_{2}$ orchestrates cAMP signaling for male fertility. Proc Natl Acad Sci 101: 13483-13488.

Nomura M, Beltrán C, Darszon A, Vacquier VD. 2005. A soluble adenylyl cyclase from sea urchin spermatozoa. Gene 353: 231-238.

Ogawa H, Qui Y, Ogata CM, Misono KS. 2004. Crystal structure of hormone-bound atrial natriuretic peptide receptor extracellular domain: Rotation mechanism for transmembrane signal transduction. J Biol Chem 279: 28625-28631.

Okunade GW, Miller ML, Pyne GJ, Sutliff RL, O'Connor KT, Neumann JC, Andringa A, Miller DA, Prasad V, Doetschman T, et al. 2004. Targeted ablation of plasma membrane $\mathrm{Ca}^{2+}$-ATPase (PMCA) 1 and 4 indicates a major housekeeping function for PMCA1 and a critical role in hyperactivated sperm motility and male fertility for PMCA4. $J$ Biol Chem 279: 33742-33750.

Oren-Benaroya R, Orvieto R, Gakamsky A, Pinchasov M, Eisenbach M. 2008. The sperm chemoattractant secreted from human cumulus cells is progesterone. Hum Reprod 23: 2339-2345.

Perez-Cerezales S, Boryshpolets S, Afanzar O, Brandis A, Nevo R, Kiss V, Eisenbach M. 2015. Involvement of opsins in mammalian sperm thermotaxis. Sci Rep 5: 16146.

Pichlo M, Bungert-Plümke S, Weyand I, Seifert R, Bönigk W, Strünker T, Kashikar ND, Goodwin N, Müller A, Pelzer P, et al. 2014. High density and ligand affinity confer ultrasensitive signal detection by a guanylyl cyclase chemoreceptor. J Cell Biol 206: 541-557.

Potter LR. 2011. Guanylyl cyclase structure, function and regulation. Cell Signal 23: 1921-1926.

Pugh ENJ, Lamb TD. 2000. Phototransduction in vertebrate rods and cones: Molecular mechanisms of amplification, recovery and light adaptation. In Handbook of biological physics (ed. Stavenga DG, DeGrip WJ, Pugh ENJ), pp. 183-255. Elsevier, Amsterdam.

Qi H, Moran MM, Navarro B, Chong JA, Krapivinsky G, Krapivinsky L, Kirichok Y, Ramsey IS, Quill TA, Clapham DE. 2007. All four CatSper ion channel proteins are required for male fertility and sperm cell hyperactivated motility. Proc Natl Acad Sci 104: 1219-1223.

Quill TA, Sugden SA, Rossi KL, Doolittle LK, Hammer RE, Garbers DL. 2003. Hyperactivated sperm motility driven by CatSper2 is required for fertilization. Proc Natl Acad Sci 100: 14869-14874.

Ramsey IS, Moran MM, Chong JA, Clapham DE. 2006. A voltage-gated proton-selective channel lacking the pore domain. Nature 440: 1213-1216.

Ren D, Navarro B, Perez G, Jackson AC, Hsu S, Shi Q, Tilly JL, Clapham DE. 2001. A sperm ion channel required for sperm motility and male fertility. Nature 413: 603-609.

Rich TC, Fagan KA, Nakata H, Schaack J, Cooper DMF, Karpen JW. 2000. Cyclic nucleotide-gated channels colocalize with adenylyl cyclase in regions of restricted cAMP diffusion. J Gen Physiol 116: 147-161.

Rich TC, Tse TE, Rohan JG, Schaack J, Karpen JW. 2001. In vivo assessment of local phosphodiesterase activity using tailored cyclic nucleotide-gated channels as cAMP sensors. J Gen Physiol 118: 63-77.

Rothschild L. 1963. Non-random distribution of bull spermatozoa in a drop of sperm suspension. Nature 198: $1221-1222$.

Santi CM, Martinez-Lopez P, de la Vega-Beltran JL, Butler A, Alisio A, Darszon A, Salkoff L. 2010. The SLO3 spermspecific potassium channel plays a vital role in male fertility. FEBS Lett 584: 1041-1046.

Sasaki M, Takagi M, Okamura Y. 2006. A voltage sensordomain protein is a voltage-gated proton channel. Science 312: 589592.

Schiffer C, Müller A, Egeberg DL, Alvarez L, Brenker C, Rehfeld A, Frederiksen H, Wäschle B, Kaupp UB, Balbach $\mathrm{M}$, et al. 2014. Direct action of endocrine disrupting chemicals on human sperm. EMBO Rep 15: 758-765.

Schneeweis DM, Schnapf JL. 1995. Photovoltage of rods and cones in the macaque retina. Science 268: 1053-1056.

Schreiber M, Wei A, Yuan A, Gaut J, Saito M, Salkoff L. 1998. Slo3, a novel $\mathrm{pH}$-sensitive $\mathrm{K}^{+}$channel from mammalian spermatocytes. J Biol Chem 273: 3509-3516.

Schuh K, Cartwright EJ, Jankevics E, Bundschu K, Liebermann J, Williams JC, Armesilla AL, Emerson M, Oceandy D, Knobeloch KP, et al. 2004. Plasma membrane $\mathrm{Ca}^{2+}$ ATPase 4 is required for sperm motility and male fertility. J Biol Chem 279: 28220-28226.

Scott K, Zuker C. 1998. TRP, TRPL and trouble in photoreceptor cells. Curr Opinion Neurobiol 8: 383-388.

Seifert R, Flick M, Bönigk W, Alvarez L, Trötschel C, Poetsch A, Müller A, Goodwin N, Pelzer P, Kashikar ND, et al. 2015. The CatSper channel controls chemosensation in sea urchin sperm. EMBO J 34: 379-392.

Servin-Vences MR, Tatsu Y, Ando H, Guerrero A, Yumoto N, Darszon A, Nishigaki T. 2012. A caged progesterone analog alters intracellular $\mathrm{Ca}^{2+}$ and flagellar bending in human sperm. Reproduction 144: 101-109.

Shiba K, Baba SA, Inoue T, Yoshida M. 2008. $\mathrm{Ca}^{2+}$ bursts occur around a local minimal concentration of attractant 
and trigger sperm chemotactic response. Proc Natl Acad Sci 105: 19312-19317.

Smith JF, Syritsyna O, Fellous M, Serres C, Mannowetz N, Kirichok Y, Lishko PV. 2013. Disruption of the principal, progesterone-activated sperm $\mathrm{Ca}^{2+}$ channel in a CatSper2-deficient infertile patient. Proc Natl Acad Sci 110: $6823-6828$.

Sourjik V, Berg HC. 2004. Functional interactions between receptors in bacterial chemotaxis. Nature 428: 437 441.

Steegborn C, Litvin TN, Levin LR, Buck J, Wu H. 2005. Bicarbonate activation of adenylyl cyclase via promotion of catalytic active site closure and metal recruitment. Nat Struct Mol Biol 12: 32-37.

Strünker T, Weyand I, Bönigk W, Van Q, Loogen A, Brown JE, Kashikar N, Hagen V, Krause E, Kaupp UB. 2006. A $\mathrm{K}^{+}$-selective cGMP-gated ion channel controls chemosensation of sperm. Nat Cell Biol 8: 1149-1154.

Strünker T, Goodwin N, Brenker C, Kashikar ND, Weyand I, Seifert R, Kaupp UB. 2011. The CatSper channel mediates progesterone-induced $\mathrm{Ca}^{2+}$ influx in human sperm. Nature 471: 382-386.

Su YH, Vacquier VD. 2002. A flagellar $\mathrm{K}^{+}$-dependent $\mathrm{Na}^{+} /$ $\mathrm{Ca}^{2+}$ exchanger keeps $\mathrm{Ca}^{2+}$ low in sea urchin spermatozoa. Proc Natl Acad Sci 99: 6743-6748.

Su YH, Vacquier VD. 2006. Cyclic GMP-specific phosphodiesterase-5 regulates motility of sea urchin spermatozoa. Mol Biol Cell 17: 114-121.

Su TW, Xue L, Ozcan A. 2012. High-throughput lensfree 3D tracking of human sperms reveals rare statistics of helical trajectories. Proc Natl Acad Sci 109: 16018-16022.

Suarez SS. 2008. Control of hyperactivation in sperm. Hum Reprod Update 14: 647-657.

Suarez SS, Varosi SM, Dai X. 1993. Intracellular calcium increases with hyperactivation in intact, moving hamster sperm and oscillates with the flagellar beat cycle. Proc Natl Acad Sci 90: 4660-4664.

Takai H, Morisawa M. 1995. Change in intracellular $\mathrm{K}^{+}$ concentration caused by external osmolality change regulates sperm motility of marine and freshwater teleosts. J Cell Sci 108: 1175-1181.

Tavares RS, Mansell S, Barratt CL, Wilson SM, Publicover SJ, Ramalho-Santos J. 2013. p, $\mathrm{p}^{\prime}$-DDE activates CatSper and compromises human sperm function at environmentally relevant concentrations. Hum Reprod 28: 3167-3177.

Teves ME, Barbano F, Guidobaldi HA, Sanchez R, Miska W, Giojalas LC. 2006. Progesterone at the picomolar range is a chemoattractant for mammalian spermatozoa. Fertil Steril 86: 745-749.

Teves ME, Guidobaldi HA, Unates DR, Sanchez R, Miska W, Publicover SJ, Morales Garcia AA, Giojalas LC. 2009. Molecular mechanism for human sperm chemotaxis mediated by progesterone. PLoS ONE 4: e8211.

Tsunoda S, Sierralta J, Sun Y, Bodner R, Suzuki E, Becker A, Socolich M, Zuker CS. 1997. A multivalent PDZ-domain protein assembles signalling complexes in a G-proteincoupled cascade. Nature 388: 243-249.

Vaandrager AB. 2002. Structure and function of the heatstable enterotoxin receptor/guanylyl cyclase C. Mol Cell Biochem 230: 73-83.
Vines CA, Yoshida K, Griffin FJ, Pillai MC, Morisawa M, Yanagimachi R, Cherr GN. 2002. Motility initiation in herring sperm is regulated by reverse sodium-calcium exchange. Proc Natl Acad Sci 99: 2026-2031.

Visconti PE, Moore GD, Bailey JL, Leclerc P, Connors SA, Pan D, Olds-Clarke P, Kopf GS. 1995. Capacitation of mouse spermatozoa. II: Protein tyrosine phosphorylation and capacitation are regulated by a cAMP-dependent pathway. Development 121: 1139-1150.

Wang D, King SM, Quill TA, Doolittle LK, Garbers DL. 2003. A new sperm-specific $\mathrm{Na}^{+} / \mathrm{H}^{+}$exchanger required for sperm motility and fertility. Nat Cell Biol 5: 11171122 .

Wang D, Hu J, Bobulescu IA, Quill TA, McLeroy P, Moe OW, Garbers DL. 2007. A sperm-specific $\mathrm{Na}^{+} / \mathrm{H}^{+}$exchanger (sNHE) is critical for expression and in vivo bicarbonate regulation of the soluble adenylyl cyclase (sAC). Proc Nat Acad Sci 104: 9325-9330.

Wang H, Liu J, Cho KH, Ren D. 2009. A novel, single, transmembrane protein CATSPERG is associated with CATSPER1 channel protein. Biol Reprod 81: 539-544.

Wennemuth G, Babcock DF, Hille B. 2003a. Calcium clearance mechanisms of mouse sperm. J Gen Physiol 122: $115-128$.

Wennemuth G, Carlson AE, Harper AJ, Babcock DF. 2003b. Bicarbonate actions on flagellar and $\mathrm{Ca}^{2+}$-channel responses: initial events in sperm activation. Development 130: $1317-1326$

Wertheimer E, Krapf D, de la Vega-Beltran JL, Sanchez-Cardenas C, Navarrete F, Haddad D, Escoffier J, Salicioni AM, Levin LR, Buck J, et al. 2013. Compartmentalization of distinct cAMP signaling pathways in mammalian sperm. J Biol Chem 288: 35307-35320.

Whitlock GG, Lamb TD. 1999. Variability in the time course of single photon responses from toad rods: Termination of rhodopsin's activity. Neuron 23: 337-351.

Wilson EM, Chinkers M. 1995. Identification of sequences mediating guanylyl cyclase dimerization. Biochemistry 34: 4696-4701.

Winet H, Bernstein GS, Head J. 1984. Observations on the response of human spermatozoa to gravity, boundaries and fluid shear. J Reprod Fertil 70: 511-523.

Wood CD, Nishigaki T, Furuta T, Baba SA, Darszon A. 2005. Real-time analysis of the role of $\mathrm{Ca}^{2+}$ in flagellar movement and motility in single sea urchin sperm. J Cell Biol 169: $725-731$.

Yanagimachi R, Cherr G, Matsubara T, Andoh T, Harumi T, Vines C, Pillai M, Griffin F, Matsubara H, Weatherby T, et al. 2013. Sperm attractant in the micropyle region of fish and insect eggs. Biol Reprod 88: 47.

Yang C, Zeng XH, Zhou Y, Xia XM, Lingle CJ. 2011. LRRC52 (leucine-rich-repeat-containing protein 52), a testis-specific auxiliary subunit of the alkalization-activated Slo3 channel. Proc Natl Acad Sci 108: 19419-19424.

Yau KW, Hardie RC. 2009. Phototransduction motifs and variations. Cell 139: 246-264.

Yu H, Olshevskaya E, Duda T, Seno K, Hayashi F, Sharma RK, Dizhoor AM, Yamazaki A. 1999. Activation of retinal guanylyl cyclase-1 by $\mathrm{Ca}^{2+}$-binding proteins involves its dimerization. J Biol Chem 274: 1554715555 . 
D. Wachten et al.

Zeng XH, Yang C, Kim ST, Lingle CJ, Xia XM. 2011. Deletion of the Slo3 gene abolishes alkalization-activated $\mathrm{K}^{+}$ current in mouse spermatozoa. Proc Natl Acad Sci 108: 5879-5884.

Zeng XH, Navarro B, Xia XM, Clapham DE, Lingle CJ. 2013. Simultaneous knockout of Slo3 and CatSper1 abolishes all alkalization- and voltage-activated current in mouse spermatozoa. J Gen Physiol 142: 305-313.

Zeng XH, Yang C, Xia XM, Liu M, Lingle CJ. 2015. SLO3 auxiliary subunit LRRC52 controls gating of sperm
KSPER currents and is critical for normal fertility. Proc Natl Acad Sci 112: 2599-2604.

Zhang Y, Malekpour M, Al-Madani N, Kahrizi K, Zanganeh M, Lohr NJ, Mohseni M, Mojahedi F, Daneshi A, Najmabadi H, et al. 2007. Sensorineural deafness and male infertility: A contiguous gene deletion syndrome. J Med Genet 44: 233-240.

Zhang Z, Liu J, Meriano J, Ru C, Xie S, Luo J, Sun Y. 2016. Human sperm rheotaxis: a passive physical process. Sci Rep 6: 23553. 


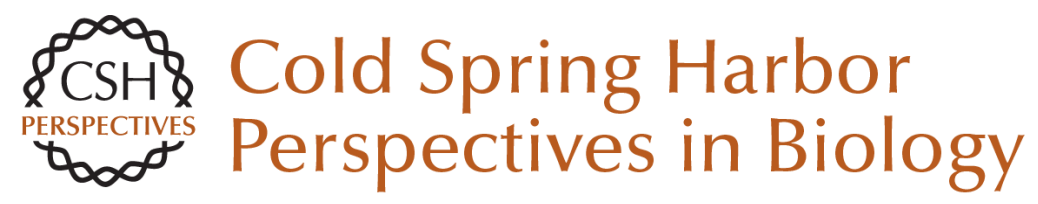

\section{Sperm Sensory Signaling}

Dagmar Wachten, Jan F. Jikeli and U. Benjamin Kaupp

Cold Spring Harb Perspect Biol 2017; doi: 10.1101/cshperspect.a028225 originally published online January 6, 2017

\section{Subject Collection Cilia}

Ciliary Mechanisms of Cyst Formation in Polycystic Kidney Disease

Ming Ma, Anna-Rachel Gallagher and Stefan Somlo

Photoreceptor Cilia and Retinal Ciliopathies Kinga M. Bujakowska, Qin Liu and Eric A. Pierce

G-Protein-Coupled Receptor Signaling in Cilia Kirk Mykytyn and Candice Askwith

Evolution of Cilia David R. Mitchell

Transition Zone Migration: A Mechanism for Cytoplasmic Ciliogenesis and Postaxonemal Centriole Elongation

Tomer Avidor-Reiss, Andrew Ha and Marcus L. Basiri

Cilia and Obesity

Christian Vaisse, Jeremy F. Reiter and Nicolas F. Berbari

Posttranslational Modifications of Tubulin and Cilia

Dorota Wloga, Ewa Joachimiak, Panagiota Louka, et al.
Cilia in Left-Right Symmetry Breaking Kyosuke Shinohara and Hiroshi Hamada

Discovery, Diagnosis, and Etiology of Craniofacial Ciliopathies Elizabeth N. Schock and Samantha A. Brugmann

Axoneme Structure from Motile Cilia Takashi Ishikawa

Cilia and Ciliopathies in Congenital Heart Disease Nikolai T. Klena, Brian C. Gibbs and Cecilia W. Lo

Sperm Sensory Signaling Dagmar Wachten, Jan F. Jikeli and U. Benjamin Kaupp

\section{Primary Cilia and Coordination of Receptor} Tyrosine Kinase (RTK) and Transforming Growth Factor $\beta$ (TGF- $\beta$ ) Signaling Søren T. Christensen, Stine K. Morthorst, Johanne B. Mogensen, et al.

Primary Cilia and Mammalian Hedgehog Signaling Fiona Bangs and Kathryn V. Anderson

For additional articles in this collection, see http://cshperspectives.cshlp.org/cgi/collection/

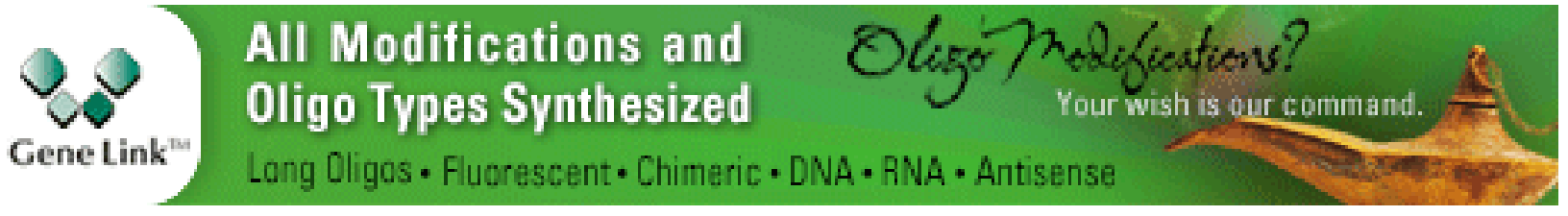


Radial Spokes--A Snapshot of the Motility Regulation, Assembly, and Evolution of Cilia and Flagella

Xiaoyan Zhu, Yi Liu and Pinfen Yang
Cilia and Mucociliary Clearance

Ximena M. Bustamante-Marin and Lawrence E. Ostrowski

For additional articles in this collection, see http://cshperspectives.cshlp.org/cgi/collection/

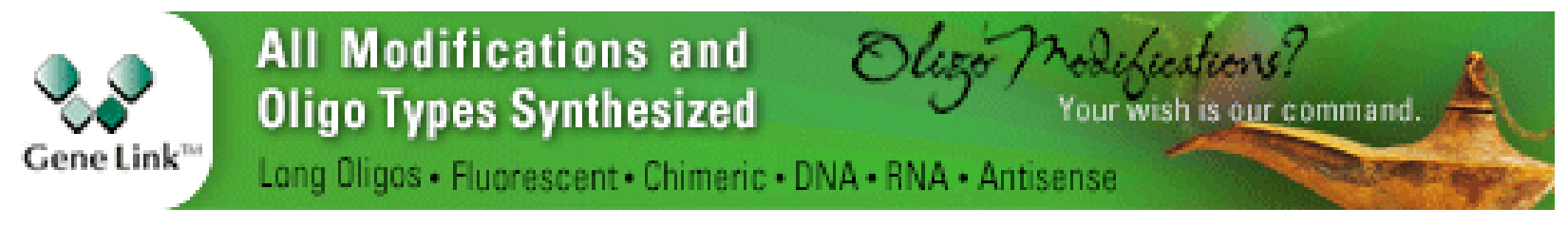

Copyright @ 2017 Cold Spring Harbor Laboratory Press; all rights reserved 